Supporting Information

\title{
Ladder Distyrylbenzenes with Silicon and Chalcogen Bridges: Synthesis, Structures, and Properties
}

Kazuhiro Mouri, Atsushi Wakamiya, Hiroshi Yamada, Takashi Kajiwara, and Shigehiro Yamaguchi*

Department of Chemistry, Graduate School of Science, Nagoya University, and SORST, Japan Science and Technology Agency (JST),

Chikusa, Nagoya 464-8602

Email Address: yamaguchi@chem.nagoya-u.ac.jp

\section{Expermental Section}

General. Melting point (mp) determination was performed using a Yanaco MP-S3 instrument. ${ }^{1} \mathrm{H}$ and ${ }^{13} \mathrm{C}$ NMR spectra were measured with a JEOL A-400 spectrometer. UV-visible absorption and fluorescence spectra were measured with a Shimadzu UV-3150 spectrometer and a F-4500 Hitachi spectrometer, respectively, in degassed spectral grade THF. Cyclic voltammograms were recorded on a CHI600A instrument. Thin layer chromatography (TLC) was performed on plates coated with $0.25 \mathrm{~mm}$ thick silica gel 60F-254 (Merck). Column chromatography was performed using a Fuji Silysia silica gel PSQ60B $(60 \mu \mathrm{m})$. All reactions were carried out under argon atmosphere.

\section{Starting Materials Synthesis.}

1-(Ethoxydimethylsilyl)-2-(trimethylsilylethynyl)benzene (8). To a solution of (2-bromophenyl)trimethylsilylacetylene $(15 \mathrm{~g}, 60 \mathrm{mmol})$ in $\mathrm{Et}_{2} \mathrm{O}$ was added a hexane solution of $n$-BuLi (1.6 M, $37.5 \mathrm{~mL}, 60 \mathrm{mmol})$ dropwise at $-78^{\circ} \mathrm{C}$. After stirring the mixture for 2.5 $\mathrm{h},\left(\mathrm{Et}_{2} \mathrm{~N}\right) \mathrm{Me}_{2} \mathrm{SiCl}(13.2 \mathrm{~g}, 80 \mathrm{mmol})$ was added via syringe at the same temperature. The reaction mixture was allowed to warm to room temperature and stirred for $9 \mathrm{~h}$. EtOH (60 $\mathrm{mL}, 1 \mathrm{~mol})$ and $\mathrm{NH}_{4} \mathrm{Cl}(6.7 \mathrm{~g}, 126 \mathrm{mmol})$ were added and the mixture was stirred at room temperature for $5 \mathrm{~h}$. The reaction mixture was filtered and the filtrate was concentrated under reduced pressure. After passing the resulting mixture through a silica gel column (hexane/AcOEt 20/1, $R_{\mathrm{f}}=0.46$ ), distillation under reduced pressure afforded $14.6 \mathrm{~g}$ (53 


\section{Scheme S1}<smiles>C[AsH2]C#Cc1ccccc1Br</smiles><smiles>[R]C#Cc1ccccc1SCCOC</smiles>
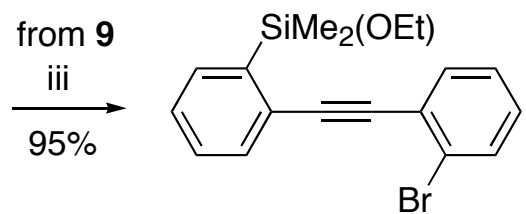

1

$$
\left.\begin{array}{l}
8\left(\mathrm{R}=\mathrm{SiMe}_{3}\right) \\
\mathbf{9}(\mathrm{R}=\mathrm{H})
\end{array}\right] \mathrm{ii}, 92 \%
$$$$
\text { from } 9\lfloor\text { iv, 49\% }
$$

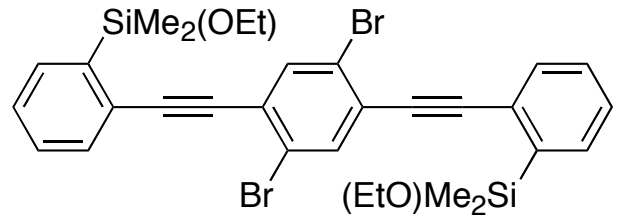

$4 b$
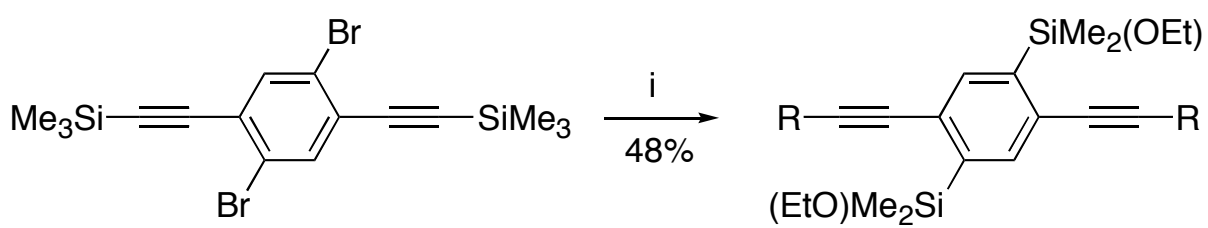

$\left.\begin{array}{l}10\left(\mathrm{R}=\mathrm{SiMe}_{3}\right) \\ 11(\mathrm{R}=\mathrm{H})\end{array}\right] \mathrm{ii}, 75 \%$
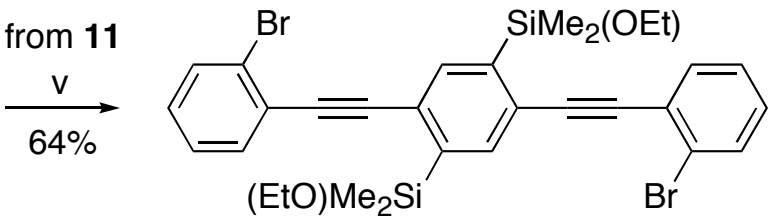

$4 a$

Reagents and conditions: i, 1) $n$-BuLi, $\mathrm{Et}_{2} \mathrm{O}$; 2) $\left(\mathrm{Et}_{2} \mathrm{~N}\right) \mathrm{Me}_{2} \mathrm{SiCl}$; 3) $\mathrm{EtOH}$, cat. $\mathrm{NH}_{4} \mathrm{Cl}$; ii, $\mathrm{K}_{2} \mathrm{CO}_{3}$, THF/EtOH; iii, 1-bromo-2-iodobenzene, $\mathrm{PdCl}_{2}\left(\mathrm{PPh}_{3}\right)_{2}$, Cul, Et $\mathrm{Et}_{3} \mathrm{~N}$; iv, 1,4-dibromo2,5-diiodobenzene, $\mathrm{PdCl}_{2}\left(\mathrm{PPh}_{3}\right)_{2}$, Cul, 1/1 $\mathrm{Et}_{3} \mathrm{~N} / \mathrm{THF} ; \mathrm{v}$, 1-bromo-2-iodobenzene, $\mathrm{Pd}\left(\mathrm{PPh}_{3}\right)_{4}$, Cul, 1/4 (i-Pr) ${ }_{2} \mathrm{NH} / \mathrm{THF}$.

mmol) of 8 in $88 \%$ yield as colorless liquid $\left(62-69{ }^{\circ} \mathrm{C}, 0.2 \mathrm{mmHg}\right):{ }^{1} \mathrm{H}$ NMR $(400 \mathrm{MHz}$, $\left.\mathrm{CDCl}_{3}\right): \delta 7.64-7.60(\mathrm{~m}, 1 \mathrm{H}), 7.51-7.46(\mathrm{~m}, 1 \mathrm{H}), 7.33-7.29(\mathrm{~m}, 2 \mathrm{H}), 3.78(\mathrm{q}, J=7.1 \mathrm{~Hz}, 2 \mathrm{H})$, $1.25(\mathrm{t}, J=7.1 \mathrm{~Hz}, 3 \mathrm{H}), 0.47(\mathrm{~s}, 6 \mathrm{H}), 0.25(\mathrm{~s}, 9 \mathrm{H}) .{ }^{13} \mathrm{C} \mathrm{NMR}\left(100 \mathrm{MHz}, \mathrm{CDCl}_{3}\right): \delta$ 141.17, $134.14,132.82,129.09,127.69,127.67,106.47,96.92,58.80,18.54,-0.26,-1.29$. HRMS(EI): 276.1375. Calcd for $\mathrm{C}_{15} \mathrm{H}_{24} \mathrm{OSi}_{2}: 276.1336$.

1-(Ethoxydimethylsilyl)-2-ethynylbenzene (9). To a solution of 8 in $100 \mathrm{~mL}$ of THF was 
added $\mathrm{K}_{2} \mathrm{CO}_{3}(0.73 \mathrm{~g}, 5.3 \mathrm{mmol})$ and $\mathrm{EtOH}(100 \mathrm{~mL}, 1.7 \mathrm{~mol})$ and the mixture was stirred at room temperature for $22 \mathrm{~h}$. After filtration, the filtrate was concentrated under reduced pressure. The resulting mixture was subjected to a silica gel column chromatography (hexane/AcOEt 20/1, $\left.R_{\mathrm{f}}=0.48\right)$ to afford $9.9 \mathrm{~g}$ of $9(49 \mathrm{mmol})$ in $92 \%$ yield as pale yellow liquid: ${ }^{1} \mathrm{H}$ NMR (400 MHz, $\mathrm{CDCl}_{3}$ ): $\delta$ 7.65-7.61 (m, 1H), 7.55-7.50 (m, 1H), 7.37-7.31 (m, $2 \mathrm{H}), 3.77(\mathrm{q}, J=7.1 \mathrm{~Hz}, 2 \mathrm{H}), 3.21(\mathrm{~s}, 1 \mathrm{H}) 1.25(\mathrm{t}, J=7.1 \mathrm{~Hz}, 3 \mathrm{H}), 0.48(\mathrm{~s}, 6 \mathrm{H}) . \quad{ }^{13} \mathrm{C} \mathrm{NMR}$ $\left(100 \mathrm{MHz}, \mathrm{CDCl}_{3}\right): \delta 141.29,134.24,133.27,129.21,127.95,126.71,84.86,79.95,58.83$, 18.47, -1.25. HRMS(EI): 204.0969. Calcd for $\mathrm{C}_{12} \mathrm{H}_{16} \mathrm{OSi}: 204.0970$.

[2-(Ethoxydimethylsilyl)phenyl](2-bromophenyl)acetylene (1). To a mixture of 2-bromoiodobenzene (2.8 g, $10 \mathrm{mmol}), \mathrm{PdCl}_{2}\left(\mathrm{PPh}_{3}\right)_{2}(140 \mathrm{mg}, 0.2 \mathrm{mmol})$, and $\mathrm{CuI}(0.78 \mathrm{mg}$, $0.4 \mathrm{mmol})$ in $\mathrm{Et}_{3} \mathrm{~N}(15 \mathrm{~mL})$ was added a $\mathrm{Et}_{3} \mathrm{~N}(10 \mathrm{~mL})$ solution of $9(2.1 \mathrm{~g}, 11 \mathrm{mmol})$ at room temperature. The reaction mixture was stirred at the same temperature for $10 \mathrm{~h}$. After filtration through Celite, the filtrate was concentrated under reduced pressure. The resulting mixture was subjected to a silica gel column chromatography (hexane/AcOEt 20/1, $R_{\mathrm{f}}=0.28$ ) to afford $3.4 \mathrm{~g}(9.5 \mathrm{mmol})$ of $\mathbf{1 0}$ in $95 \%$ yield as pale yellow liquid: ${ }^{1} \mathrm{H}$ NMR (400 $\mathrm{MHz}$, $\left.\mathrm{CDCl}_{3}\right): \delta 7.68-7.55(\mathrm{~m}, 4 \mathrm{H}), 7.39-7.36(\mathrm{~m}, 2 \mathrm{H}), 7.30(\mathrm{t}, J=7.3 \mathrm{~Hz}, 1 \mathrm{H}), 7.19(\mathrm{t}, J=7.3 \mathrm{~Hz}$, $1 \mathrm{H}), 3.79(\mathrm{q}, J=7.1 \mathrm{~Hz}, 2 \mathrm{H}), 1.24(\mathrm{t}, J=7.1 \mathrm{~Hz}, 3 \mathrm{H}), 0.53(\mathrm{~s}, 6 \mathrm{H}) . \quad{ }^{13} \mathrm{C} \mathrm{NMR}(100 \mathrm{MHz}$, $\left.\mathrm{CDCl}_{3}\right): \delta 140.63,134.32,133.18,132.95,132.51,129.35,129.32,127.83,127.52,127.06$, 125.62, 125.29, 95.15, 90.41, 58.83, 18.51, -0.97. HRMS(EI): 358.0381. Calcd for $\mathrm{C}_{18} \mathrm{H}_{19}$ BrOSi: 358.0389.

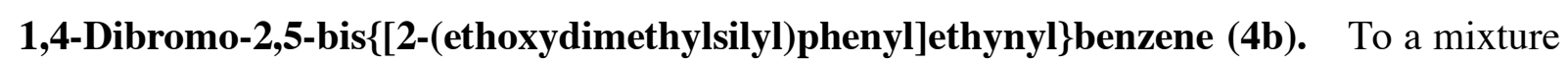
of 1,4-dibromo-2,5-diiodobenzene (24 g, $50 \mathrm{mmol}), \mathrm{PdCl}_{2}\left(\mathrm{PPh}_{3}\right)_{2}(702 \mathrm{mg}, 1.0 \mathrm{mmol})$, and $\mathrm{CuI}(380 \mathrm{mg}, 2.0 \mathrm{mmol})$ in a $1 / 1 \mathrm{Et}_{3} \mathrm{~N} / \mathrm{THF}$ mixed solvent $(250 \mathrm{~mL})$ was added a solution of 9 ( $21 \mathrm{~g}, 103 \mathrm{mmol})$ in a $1 / 1 \mathrm{Et}_{3} \mathrm{~N} / \mathrm{THF}$ mixed solvent. The mixture was then stirred at room temperature for $10 \mathrm{~h}$. After filtration through Celite, the filtrate was concentrated under reduced pressure. Recrystallization of the resulting mixture from AcOEt afforded $15.8 \mathrm{~g}$ (25 mmol) of $\mathbf{4 b}$ in $49 \%$ yield as white solid: mp. $135-137{ }^{\circ} \mathrm{C} . \quad{ }^{1} \mathrm{H} \mathrm{NMR}\left(400 \mathrm{MHz}, \mathrm{CDCl}_{3}\right): \delta$ $7.77(\mathrm{~s}, 2 \mathrm{H}), 7.69-7.63(\mathrm{~m}, 4 \mathrm{H}), 7.43-7.36(\mathrm{~m} \mathrm{4H}), 3.78(\mathrm{q}, J=7.1 \mathrm{~Hz}, 4 \mathrm{H}), 1.25$ (t, $J=7.1$ $\mathrm{Hz}, 6 \mathrm{H}), 0.52(\mathrm{~s}, 12 \mathrm{H}) .{ }^{13} \mathrm{C} \mathrm{NMR}\left(100 \mathrm{MHz}, \mathrm{CDCl}_{3}\right): \delta 140.95,136.08,134.43,133.15$, $129.38,128.30,126.89,126.66,123.47,97.91,89.14,58.85,18.51,-0.96$. HRMS (FAB): 638.0319. Calcd for $\mathrm{C}_{30} \mathrm{H}_{42} \mathrm{Br}_{2} \mathrm{O}_{2} \mathrm{Si}_{2}: 638.0308$.

1,4-Bis(ethoxydimethylsilyl)-2,5-bis[(trimethylsilyl)ethynyl]benzene (10). To a solution of 1,4-dibromo-2,5-[(trimethylsilyl)ethynyl]benzene (11.8 g, $27.6 \mathrm{mmol})$ in $\mathrm{Et}_{2} \mathrm{O}(100 \mathrm{~mL})$ 
was added a hexane solution of $n$-BuLi $(1.6 \mathrm{M}, 38 \mathrm{~mL}, 61 \mathrm{mmol})$ dropwise at $-78{ }^{\circ} \mathrm{C}$. After stirring for $1 \mathrm{~h},\left(\mathrm{Et}_{2} \mathrm{~N}\right) \mathrm{Me}_{2} \mathrm{SiCl}(11.4 \mathrm{~g}, 69 \mathrm{mmol})$ was added at the same temperature. The mixture was allowed to warm to room temperature, followed by stirring for $19 \mathrm{~h}$. EtOH (30 $\mathrm{mL}, 0.5 \mathrm{~mol})$ and $\mathrm{NH}_{4} \mathrm{Cl}(7.4 \mathrm{~g}, 138 \mathrm{mmol})$ were added to the mixture, followed by stirring for $5 \mathrm{~h}$. The reaction mixture was filtered and the filtrate was concentrated under reduced pressure. Recrystallization of the resulting mixture from AcOEt afforded $6.3 \mathrm{~g}(3.3 \mathrm{mmol})$ of $\mathbf{1 0}$ in $48 \%$ yield as white solid: mp. $130-132{ }^{\circ} \mathrm{C} . \quad{ }^{1} \mathrm{H}$ NMR $\left(400 \mathrm{MHz}, \mathrm{CDCl}_{3}\right.$ ): $\delta 7.70$ (s, $2 \mathrm{H}), 3.77$ (q, $J=6.8 \mathrm{~Hz}, 4 \mathrm{H}), 1.25(\mathrm{t}, J=6.8 \mathrm{~Hz}, 6 \mathrm{H}), 0.46(\mathrm{~s}, 12 \mathrm{H}), 0.25(\mathrm{~s}, 18 \mathrm{H}) .{ }^{13} \mathrm{C}$ NMR (100 MHz, $\left.\mathrm{CDCl}_{3}\right): \delta 141.94,138.38,126.76,106.49,98.87,58.88,18.52,-0.29,-1.41$. HRMS (EI): 474.2252. Calcd for $\mathrm{C}_{24} \mathrm{H}_{42} \mathrm{O}_{2} \mathrm{Si}_{4}: 474.2262$.

1,4-Bis(ethoxydimethylsilyl)-2,5-diethynylbenzene (11). To a solution of $10(5.0 \mathrm{~g}, 11$ $\mathrm{mmol})$ in $30 \mathrm{~mL}$ of THF was added $\mathrm{K}_{2} \mathrm{CO}_{3}(0.28 \mathrm{~g}, 2.1 \mathrm{mmol})$ and $\mathrm{EtOH}(30 \mathrm{~mL}, 0.43 \mathrm{~mol})$. The reaction mixture was stirred at room temperature for $30 \mathrm{~h}$, and then filtered. After concentration of the filtrate under reduced pressure, $\mathrm{Et}_{2} \mathrm{O}$ was added and the organic layer was washed with brine, dried over $\mathrm{MgSO}_{4}$, filtered, and concentrated. The resulting mixture was subjected to a silica gel column chromatography $\left(\mathrm{CH}_{2} \mathrm{Cl}_{2}, R_{\mathrm{f}}=0.43\right)$ to give $2.6 \mathrm{~g}(7.8 \mathrm{mmol})$ of 11 in 75\% yield as white solid: mp. 91-93 ${ }^{\circ} \mathrm{C}$. ${ }^{1} \mathrm{H}$ NMR $\left(400 \mathrm{MHz}, \mathrm{CDCl}_{3}\right.$ ): $\delta 7.75$ (s, $2 \mathrm{H}), 3.76(\mathrm{q}, J=7.1 \mathrm{~Hz}, 4 \mathrm{H}), 3.30(\mathrm{~s}, 2 \mathrm{H}), 1.24(\mathrm{t}, J=7.1 \mathrm{~Hz}, 6 \mathrm{H}), 0.47(\mathrm{~s}, 12 \mathrm{H}) . \quad{ }^{13} \mathrm{C} \mathrm{NMR}$ $\left(100 \mathrm{MHz}, \mathrm{CDCl}_{3}\right): \delta 142.29,138.90,126.14,84.83,81.58,58.93,18.46,-1.38$. HRMS (EI): 330.1472. Calcd for $\mathrm{C}_{18} \mathrm{H}_{26} \mathrm{O}_{2} \mathrm{Si}_{2}: 330.1471$.

1,4-Bis(2-bromo-1-phenyl)ethynyl-2,5-bis(ethoxydimethylsilyl)benzene $\quad(4 a)$. To a mixture of 2-bromoiodobenzene (3.4 g, $12 \mathrm{mmol}), \mathrm{Pd}\left(\mathrm{PPh}_{3}\right)_{4}(140 \mathrm{mg}, 0.12 \mathrm{mmol})$, and $\mathrm{CuI}$ (46 mg, $0.24 \mathrm{mmol})$ in a $1 / 4(i \text {-Pr })_{2} \mathrm{NH} / \mathrm{THF}$ mixed solvent $(10 \mathrm{~mL})$ was added a solution of $11(2.0 \mathrm{~g}, 6.0 \mathrm{mmol})$ in $2.5 \mathrm{~mL}$ of a $1 / 4(i \text {-Pr })_{2} \mathrm{NH} / \mathrm{THF}$ mixed solvent dropwise at room temperature. The reaction mixture was stirred for $48 \mathrm{~h}$. After filtration through Celite, the filtrate was concentrated under reduced pressure. The resulting mixture was passed thorough a silica gel column $\left(\mathrm{CH}_{2} \mathrm{Cl}_{2}\right)$, and purified by recrystallization from AcOEt to give $2.5 \mathrm{~g}$ (3.9 mmol) of $\mathbf{4 a}$ in $64 \%$ yield as white solid: $\mathrm{mp} .135-137{ }^{\circ} \mathrm{C}$. ${ }^{1} \mathrm{H}$ NMR $(400 \mathrm{MHz}$, $\left.\mathrm{CDCl}_{3}\right): \delta 7.91(\mathrm{~s}, 2 \mathrm{H}), 7.63(\mathrm{dd}, J=8.0 \mathrm{~Hz}, J=1.2 \mathrm{~Hz}, 2 \mathrm{H}), 7.57(\mathrm{dd}, J=7.8 \mathrm{~Hz}, 1.7 \mathrm{~Hz}$, 2H), 7.33-7.29 (m, 2H), 7.22-7.18 (m, 2H), 3.81 (q, $J=7.1 \mathrm{~Hz}, 4 \mathrm{H}), 1.25(\mathrm{t}, J=7.1 \mathrm{~Hz}, 6 \mathrm{H})$, $0.54(\mathrm{~s}, 12 \mathrm{H}) .{ }^{13} \mathrm{C}$ NMR $\left(100 \mathrm{MHz}, \mathrm{CDCl}_{3}\right): \delta 141.59,138.61,133.24,132.54,129.53$, 127.11, 126.66, 125.42, 125.28, 95.20, 92.17, 58.99, 18.52, -1.13. HRMS (FAB): 638.0300 Calcd for $\mathrm{C}_{30} \mathrm{H}_{42} \mathrm{Br}_{2} \mathrm{O}_{2} \mathrm{Si}_{2}: 638.0308$. 


\section{A Typical Procedure of Cascade-Type Anionic Cyclization}

Compound 5a. To a solution of compound $4 \mathbf{a}(640 \mathrm{mg}, 1.0 \mathrm{mmol})$ in THF (20 mL) was added a pentane solution of $t$ - BuLi $(1.57 \mathrm{M}, 2.6 \mathrm{~mL}, 4.0 \mathrm{mmol})$ dropwise at $-78{ }^{\circ} \mathrm{C}$. After stirred for $1 \mathrm{~h}$, sulfur $\left(\mathrm{S}_{8}\right)(64 \mathrm{mg}, 2.0 \mathrm{mmol})$ was added as a powder under a stream of argon. The mixture was kept at the same temperature for $10 \mathrm{~min}$ and then was allowed to warm to room temperature with stirring over $3 \mathrm{~h}$. After addition of a saturated $\mathrm{NH}_{4} \mathrm{Cl}$ aqueous solution, the mixture was extracted with $\mathrm{CHCl}_{3}$. The organic layer was washed with brine, dried over $\mathrm{MgSO}_{4}$, filtered, and concentrated under reduced pressure. The resulting mixture was successively washed with ethanol and hexane to give $180 \mathrm{mg}(0.40 \mathrm{mmol})$ of $\mathbf{5 a}$ in $40 \%$ yield as bright yellow powder: $\mathrm{mp} .>300{ }^{\circ} \mathrm{C} . \quad{ }^{1} \mathrm{H}$ NMR $\left(400 \mathrm{MHz}, \mathrm{CDCl}_{3}\right): \delta 7.91(\mathrm{~d}, J=7.8$ $\mathrm{Hz}, 2 \mathrm{H}), 7.76$ (d, J =7.8 Hz, 2H), 7.71 (s, 2H), 7.41-7.37 (m, 2H), 7.33-7.29 (m, 2H), 0.58 (s, 12H). $\left.{ }^{13} \mathrm{C} \mathrm{NMR} \mathrm{(100} \mathrm{MHz,} \mathrm{CDCl}_{3}\right): \delta 156.54,143.58,143.13,142.84,141.93,137.08$, 125.37, 124.83, 123.98, 123.96, 123.20, -3.50. HRMS (EI): 454.0696. Calcd for $\mathrm{C}_{26} \mathrm{H}_{22} \mathrm{~S}_{2} \mathrm{Si}_{2}: 454.0702$.

Compound 5b. This compound was prepared in $68 \%$ yield essentially in the same manner as described for 5a: $\mathrm{mp} .>300{ }^{\circ} \mathrm{C} . \quad{ }^{1} \mathrm{H}$ NMR $\left(400 \mathrm{MHz}, \mathrm{CDCl}_{3}\right): \delta 8.20$ (s, 2H), $\delta 7.60(\mathrm{~d}, J=$ $7.1 \mathrm{~Hz}, 2 \mathrm{H}), 7.52$ (d, J =7.1 Hz, 2H), 7.44-7.40 (m, 2H), 7.30-7.28 (m, 2H), $0.56(\mathrm{~s}, 12 \mathrm{H})$. ${ }^{13} \mathrm{C} \mathrm{NMR}\left(100 \mathrm{MHz}, \mathrm{CDCl}_{3}\right): 156.73,143.92,141.33,140.85,139.24,136.42,132.31,130.23$, 127.34, 121.66, 117.77, -3.44. HRMS (EI): 454.0701. Calcd for $\mathrm{C}_{26} \mathrm{H}_{22} \mathrm{~S}_{2} \mathrm{Si}_{2}: 454.0702$.

Compound 5c. This compound was prepared in $30 \%$ yield essentially in the same manner as described for $\mathbf{5 a}$ using selenium powder instead of sulfur powder: mp. $>300{ }^{\circ} \mathrm{C}$. ${ }^{1} \mathrm{H}$ NMR $\left(400 \mathrm{MHz}, \mathrm{CDCl}_{3}\right): \delta 8.23$ (s, 2H), 7.59 (d, $\left.J=6.8 \mathrm{~Hz}, 2 \mathrm{H}\right), 7.43-7.39$ (m, 4H), 7.31-7.27 (m, 2H), $0.56(\mathrm{~s}, 12 \mathrm{H}) .{ }^{13} \mathrm{C} \mathrm{NMR}\left(100 \mathrm{MHz}, \mathrm{CDCl}_{3}\right): \delta$ 158.63, 145.91, 142.24, 141.47, 140.43, 139.72, 132.04, 130.35, 127.29, 122.78, 122.58, -3.40. HRMS (EI): 549.9595. Calcd for $\mathrm{C}_{26} \mathrm{H}_{22} \mathrm{Se}_{2} \mathrm{Si}_{2}: 549.9590$.

\section{Oxidation of Si,S-Bridged Distyrylbenzene}

Compound 6a. To a solution of $5 \mathbf{5}(100 \mathrm{mg}, 0.22 \mathrm{mmol})$ in $\mathrm{CH}_{2} \mathrm{Cl}_{2}$ (30 mL) was added mCPBA (190mg, $1.1 \mathrm{mmol})$. The mixture was stirred at room temperature for $10 \mathrm{~h}$. After addition of a saturated $\mathrm{NaHSO}_{3}$ aqueous solution, the mixture was extracted with $\mathrm{CH}_{2} \mathrm{Cl}_{2}$. The organic layer was washed with brine, dried over $\mathrm{MgSO}_{4}$, filtered, and concentrated under reduced pressure. Recrystallization from DMSO afforded $20 \mathrm{mg}(0.040 \mathrm{mmol})$ of $\mathbf{6 a}$ in $18 \%$ 
yield as yellow solid: mp. $>300{ }^{\circ} \mathrm{C} . \quad{ }^{1} \mathrm{H}$ NMR $\left(400 \mathrm{MHz}, \mathrm{CDCl}_{3}\right): \delta 7.97(\mathrm{~s}, 2 \mathrm{H}), 7.76(\mathrm{~d}, J=$ $7.1 \mathrm{~Hz}, 2 \mathrm{H}), 7.60-7.56(\mathrm{~m}, 2 \mathrm{H}), 7.52-7.48$ (m, 2H), 7.34 (d, J =7.1 Hz, 2H), $0.62(\mathrm{~s}, 12 \mathrm{H})$. ${ }^{13} \mathrm{C}$ NMR (100 MHz, $\left.\mathrm{CDCl}_{3}\right)$ : 153.06, 143.67, 143.56, 139.74, 138.18, 133.84, 132.40, 129.71, 127.29, 125.49, 121.94, -4.24. HRMS (EI): 518.0495. Calcd for $\mathrm{C}_{26} \mathrm{H}_{22} \mathrm{O}_{4} \mathrm{~S}_{2} \mathrm{Si}_{2}:$ 518.0498.

Compound 6b. This compound was prepared in $45 \%$ yield essentially in the same manner as described for 6a: mp. $>300{ }^{\circ} \mathrm{C} . \quad{ }^{1} \mathrm{H} \mathrm{NMR}\left(400 \mathrm{MHz}, \mathrm{CDCl}_{3}\right): \delta 7.75(\mathrm{~d}, J=7.3 \mathrm{~Hz}, 2 \mathrm{H})$, $7.66(\mathrm{~d}, J=7.3 \mathrm{~Hz}, 2 \mathrm{H}), 7.61(\mathrm{~s}, 2 \mathrm{H}), 7.53-7.50(\mathrm{~m}, 2 \mathrm{H}), 7.45-7.43(\mathrm{~m}, 2 \mathrm{H}), 0.62(\mathrm{~s}, 12 \mathrm{H})$. ${ }^{13} \mathrm{C}$ NMR $\left(100 \mathrm{MHz}, \mathrm{CDCl}_{3}\right): \delta 154.83,144.63,140.99,140.19,137.17,134.18,133.34$, 130.92, 129.69, 123.57, 118.25, -4.17. HRMS (EI): 518.0474. Calcd for $\mathrm{C}_{26} \mathrm{H}_{22} \mathrm{O}_{4} \mathrm{~S}_{2} \mathrm{Si}_{2}$. 518.0498 .

\section{X-Ray Crystallography}

X-Ray Crystal Structure Analysis of Compound 5a. Single crystals of 5a suitable for X-ray crystal analysis were obtained by recrystallization from a chloroform/ethanol mixed solvent. Intensity data were collected at $103 \mathrm{~K}$ on a Rigaku Single Crystal CCD X-ray Diffractometer (Saturn 70 with MicroMax-007) with Mo K $\alpha$ radiation $(\lambda=0.71073 \AA$ ) and graphite monochromator. A total of 8827 reflections were measured at a maximum $2 \theta$ angle of $55.0^{\circ}$, of which 2583 were independent reflections $\left(R_{\text {int }}=0.0234\right)$. The structure was solved by direct methods (SHELXS-97') and refined by the full-matrix least-squares on $F^{2}$ $\left(\right.$ SHELXL-97 ${ }^{1}$ ). All non-hydrogen atoms were refined anisotropically and all hydrogen atoms were placed using AFIX instructions. The crystal data are as follows: $\mathrm{C}_{26} \mathrm{H}_{22} \mathrm{~S}_{2} \mathrm{Si}_{2}$; $\mathrm{FW}=454.74$, crystal size $0.20 \times 0.20 \times 0.10 \mathrm{~mm}^{3}$, monoclinic, $P 2_{1} / \mathrm{c}, a=8.9171(15) \AA, b=$

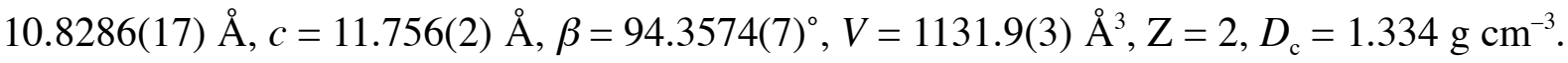
The refinement converged to $R_{1}=0.0280, \mathrm{w} R_{2}=0.0741(I>2 \sigma(I)), \mathrm{GOF}=1.053$.

X-Ray Crystal Structure Analysis of Compound 5b. Single crystals of $5 \mathbf{b}$ suitable for $\mathrm{X}$-ray crystal analysis were obtained by recrystallization from toluene/dichloromethane. Intensity data were collected at $173 \mathrm{~K}$ on a Rigaku Single Crystal CCD X-ray Diffractometer (Saturn 70 with MicroMax-007) with Mo K $\alpha$ radiation $(\lambda=0.71073 \AA$ ) and graphite monochromator. A total of 7138 reflections were measured at a maximum $2 \theta$ angle of $50.0^{\circ}$, of which 2005 were independent reflections $\left(R_{\text {int }}=0.0361\right)$. The structure was solved by direct methods (SHELXS-972) and refined by the full-matrix least-squares on $F^{2}$ $($ SHELXL-972). All non-hydrogen atoms were refined anisotropically and all hydrogen atoms were placed using AFIX instructions. The crystal data are as follows: $\mathrm{C}_{26} \mathrm{H}_{22} \mathrm{~S}_{2} \mathrm{Si}_{2}$; 
FW $=454.74$, crystal size $0.15 \times 0.10 \times 0.05 \mathrm{~mm}^{3}$, monoclinic, $P 2_{1} / \mathrm{c}, a=11.383(3) \AA, b=$ 6.8442(18) $\AA, c=15.037(4) \AA, \beta=93.264(4)^{\circ}, V=1169.6(5) \AA^{3}, \mathrm{Z}=2, D_{\mathrm{c}}=1.291 \mathrm{~g} \mathrm{~cm}^{-3}$. The refinement converged to $R_{1}=0.0309, \mathrm{w} R_{2}=0.0827(I>2 \sigma(I)), \mathrm{GOF}=0.997$.

X-Ray Crystal Structure Analysis of Compound 5c. Single crystals of 5c suitable for $\mathrm{X}$-ray crystal analysis were obtained by recrystallization from a chloroform/ethanol mixed solvent. Intensity data were collected at $123 \mathrm{~K}$ on a Rigaku Single Crystal CCD X-ray Diffractometer (Saturn 70 with MicroMax-007) with Mo K $\alpha$ radiation $(\lambda=0.71073 \AA$ ) and graphite monochromator. A total of 14669 reflections were measured at a maximum $2 \theta$ angle of $50.0^{\circ}$, of which 4035 were independent reflections $\left(R_{\text {int }}=0.0316\right)$. The structure was solved by direct methods (SHELXS-97') and refined by the full-matrix least-squares on $F^{2}$ (SHELXL-97 $7^{1}$. All non-hydrogen atoms were refined anisotropically and all hydrogen atoms were placed using AFIX instructions. The crystal data are as follows: $\mathrm{C}_{26} \mathrm{H}_{22} \mathrm{Se}_{2} \mathrm{Si}_{2}$; $\mathrm{FW}=548.54$, crystal size $0.15 \times 0.10 \times 0.05 \mathrm{~mm}^{3}$, monoclinic, $P 2_{1} / \mathrm{n}, a=8.8891(16) \AA, b=$ 9.8528(18) $\AA, c=26.162(5) \AA, \beta=90.8205(10)^{\circ}, V=2291.1(7) \AA^{3}, \mathrm{Z}=4, D_{\mathrm{c}}=1.590 \mathrm{~g} \mathrm{~cm}^{-3}$. The refinement converged to $R_{1}=0.0282, \mathrm{w} R_{2}=0.0652(I>2 \sigma(I)), \mathrm{GOF}=1.080$.

X-Ray Crystal Structure Analysis of Compound 6a. Single crystals of 6a suitable for X-ray crystal analysis were obtained by recrystallization from DMSO. Intensity data were collected at $173 \mathrm{~K}$ on a Rigaku Single Crystal CCD X-ray Diffractometer (Saturn 70 with MicroMax-007) with Mo K $\alpha$ radiation $(\lambda=0.71073 \AA$ A $)$ and graphite monochromator. A total of 8017 reflections were measured at a maximum $2 \theta$ angle of $50.0^{\circ}$, of which 2197 were independent reflections $\left(R_{\text {int }}=0.0549\right)$. The structure was solved by direct methods $\left(\right.$ SHELXS-97 ${ }^{1}$ ) and refined by the full-matrix least-squares on $F^{2}$ (SHELXL-97 ${ }^{1}$ ). All non-hydrogen atoms were refined anisotropically and all hydrogen atoms were placed using AFIX instructions. The crystal data are as follows: $\mathrm{C}_{26} \mathrm{H}_{22} \mathrm{O}_{4} \mathrm{~S}_{2} \mathrm{Si}_{2} ; \mathrm{FW}=518.74$, crystal size $0.12 \times 0.10 \times 0.03 \mathrm{~mm}^{3}$, monoclinic, $P 2_{1} / \mathrm{a}, a=13.042(4) \AA, b=6.878(2) \AA, c=14.555(5) \AA$, $\beta=106.6984(14)^{\circ}, V=1250.5(7) \AA^{3}, \mathrm{Z}=2, D_{\mathrm{c}}=1.378 \mathrm{~g} \mathrm{~cm}^{-3}$. The refinement converged to $R_{1}=0.0523, \mathrm{w} R_{2}=0.1107(I>2 \sigma(I)), \mathrm{GOF}=1.128$.

X-Ray Crystal Structure Analysis of Compound 6b. Single crystals of $6 \mathbf{b}$ suitable for $\mathrm{X}$-ray crystal analysis were obtained by recrystallization from a chloroform/ethanol mixed solvent. Intensity data were collected at $103 \mathrm{~K}$ on a Rigaku Single Crystal CCD X-ray Diffractometer (Saturn 70 with MicroMax-007) with Mo K $\alpha$ radiation $(\lambda=0.71073 \AA$ ) and graphite monochromator. A total of 8117 reflections were measured at a maximum $2 \theta$ angle of $50.0^{\circ}$, of which 2159 were independent reflections $\left(R_{\text {int }}=0.0607\right)$. The structure was 
solved by direct methods (SHELXS-97 ${ }^{1}$ ) and refined by the full-matrix least-squares on $F^{2}$ $\left(\right.$ SHELXL-97 $\left.{ }^{1}\right)$. All non-hydrogen atoms were refined anisotropically and all hydrogen atoms were placed using AFIX instructions. The crystal data are as follows: $\mathrm{C}_{26} \mathrm{H}_{22} \mathrm{O}_{4} \mathrm{~S}_{2} \mathrm{Si}_{2}$; $\mathrm{FW}=518.74$, crystal size $0.15 \times 0.10 \times 0.05 \mathrm{~mm}^{3}$, monoclinic, $P 2_{1} / \mathrm{n}, a=9.057(3) \AA, b=$

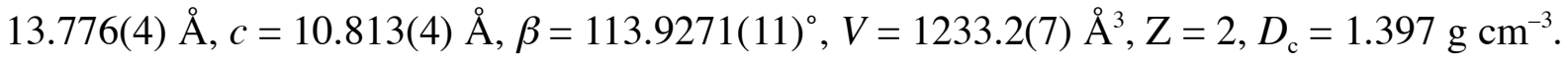
The refinement converged to $R_{1}=0.0498, \mathrm{w} R_{2}=0.1139(I>2 \sigma(I)), \mathrm{GOF}=1.115$. 
a)
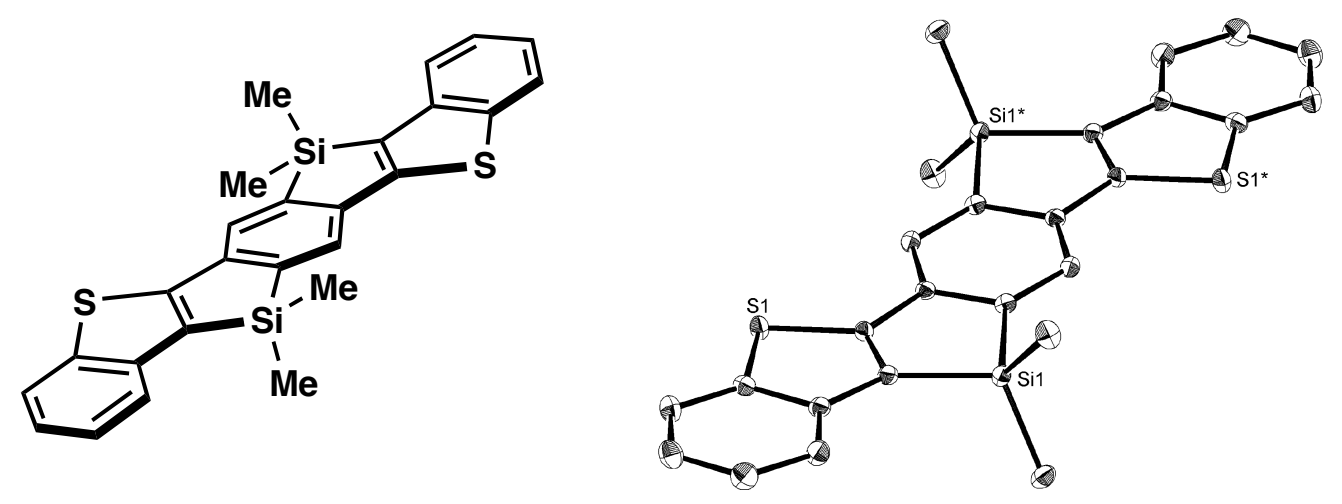

b)

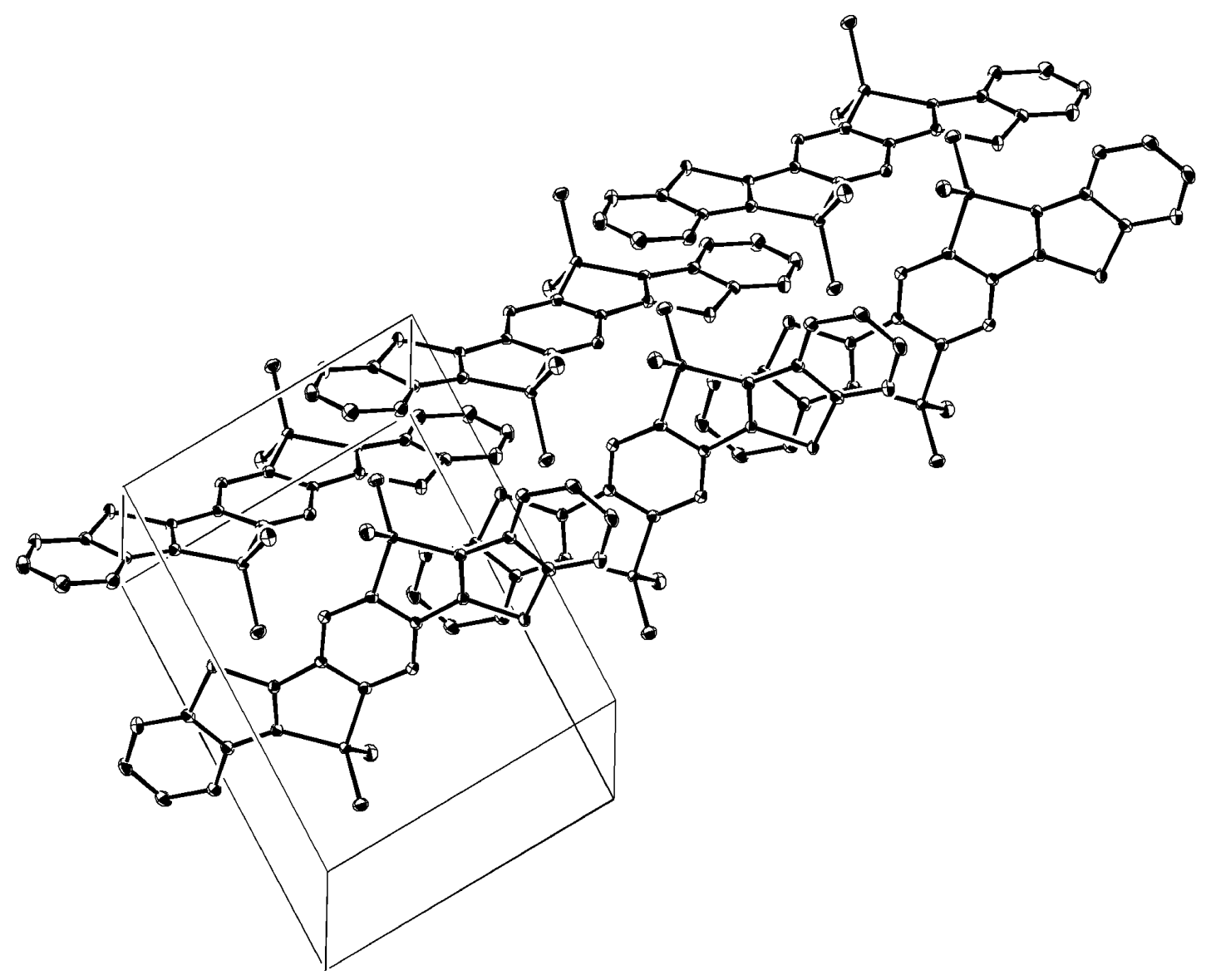

Figure S1. ORTEP drawing of 5a (50\% probability for thermal ellipsoids): a) a perspective view and b) a packing structure. Hydrogen atoms are omitted for clarity. 
a)
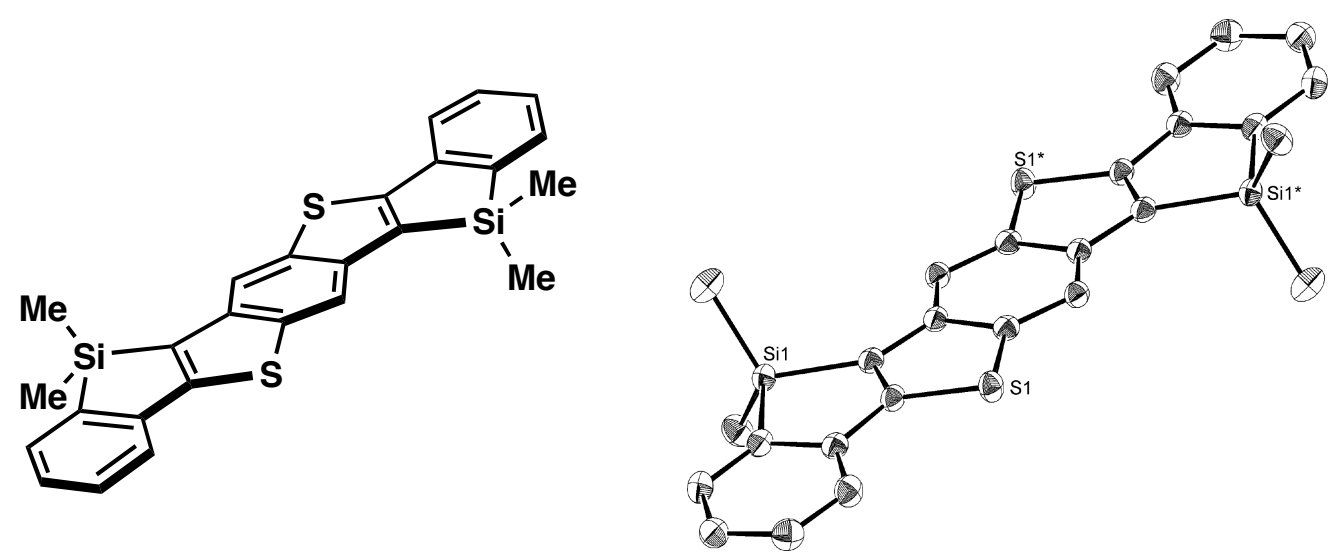

b)

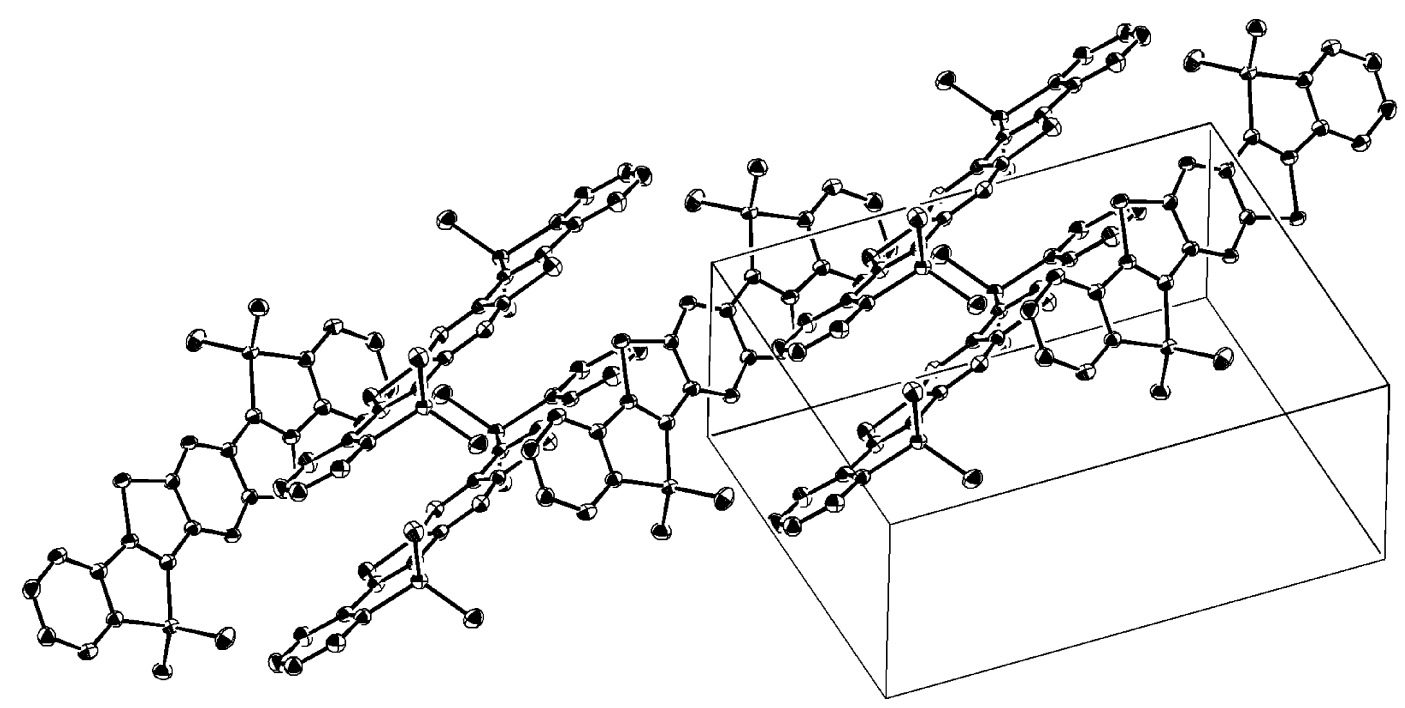

Figure S2. ORTEP drawing of $\mathbf{5 b}$ (50\% probability for thermal ellipsoids): a) a perspective view and b) a packing structure. Hydrogen atoms are omitted for clarity. 
a)
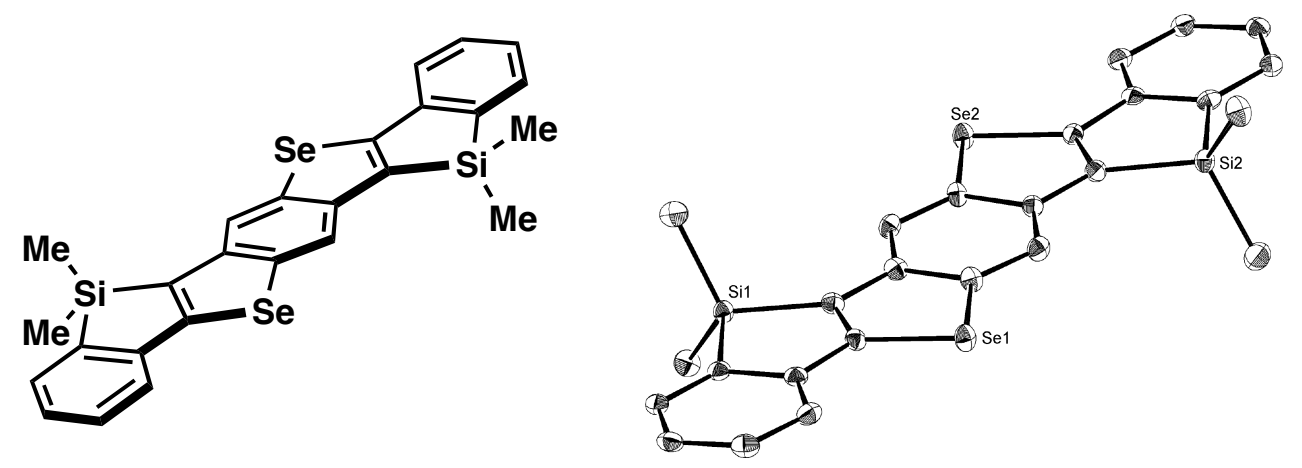

b)

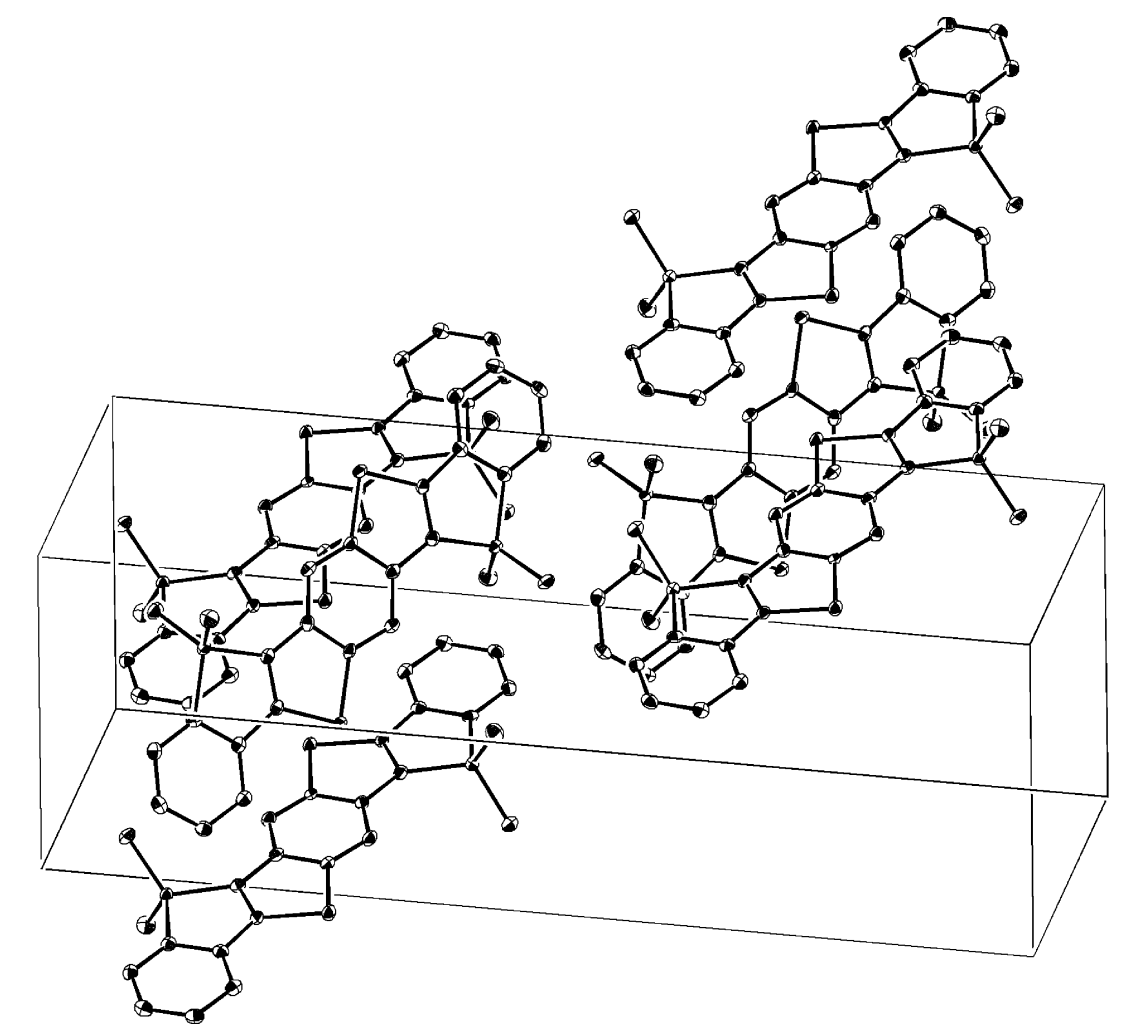

Figure S3. ORTEP drawing of 5c (50\% probability for thermal ellipsoids): a) a perspective view and b) a packing structure. Hydrogen atoms are omitted for clarity. 
a)
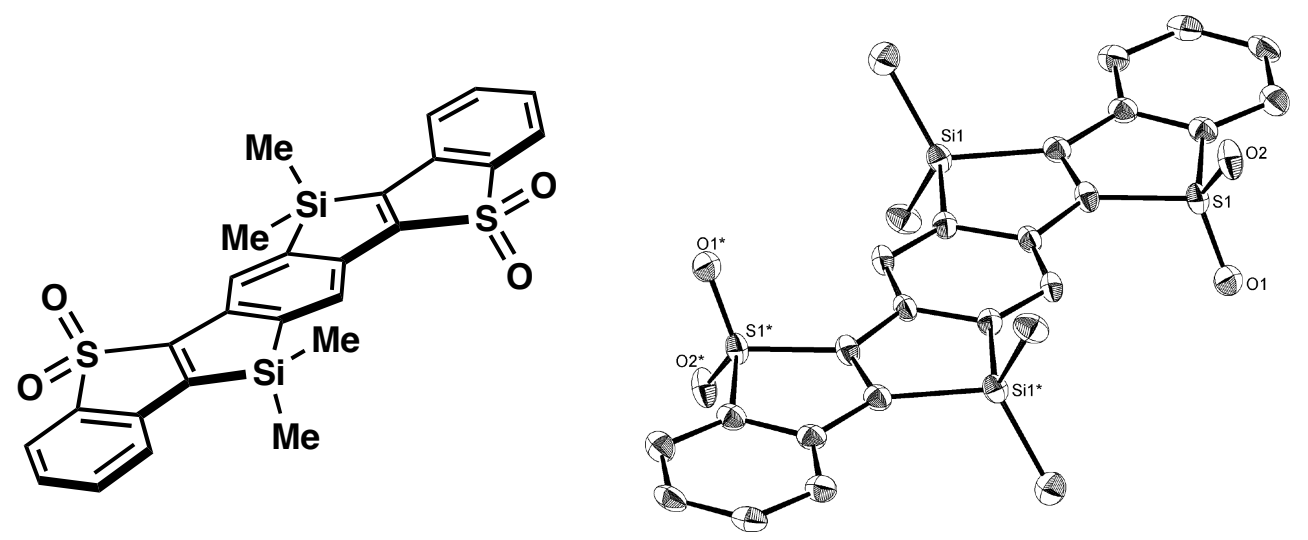

b)

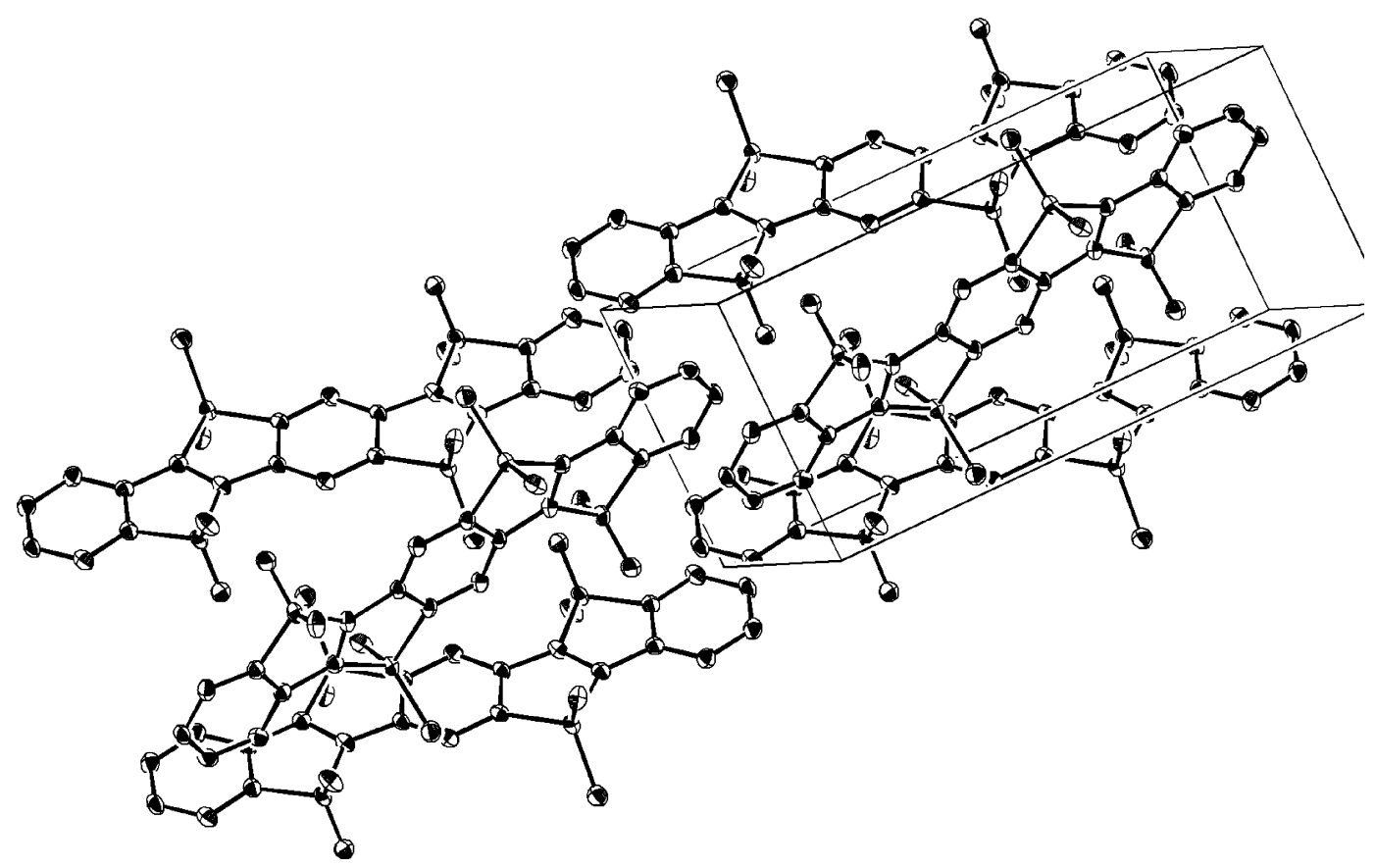

Figure S4. ORTEP drawing of $6 \mathbf{a}$ (50\% probability for thermal ellipsoids): a) a perspective view and b) a packing structure. Hydrogen atoms are omitted for clarity. 
a)
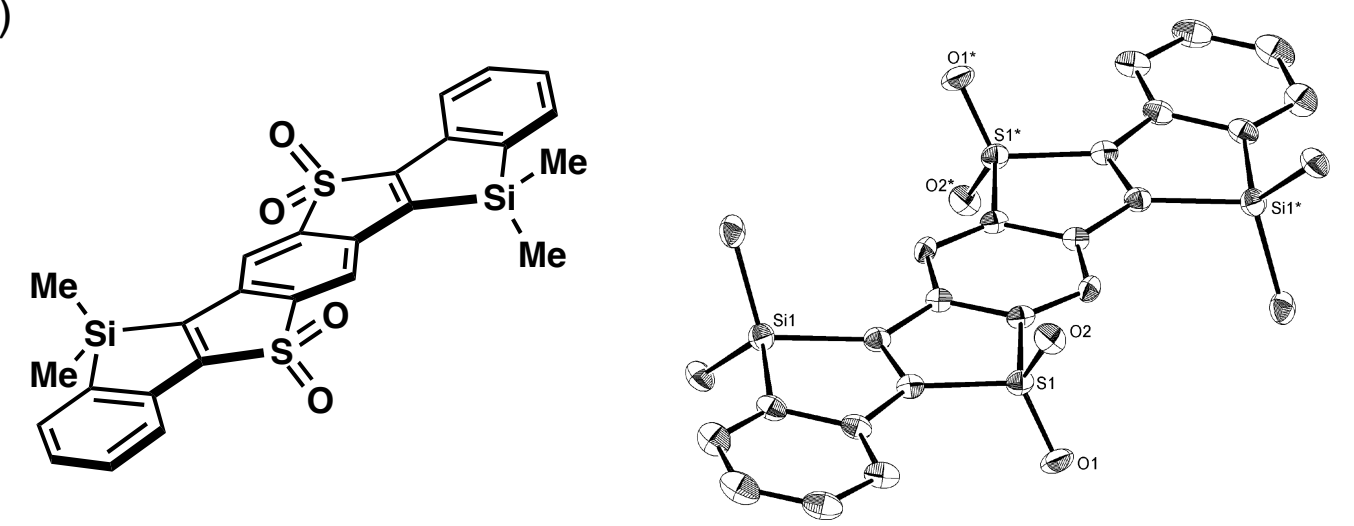

b)

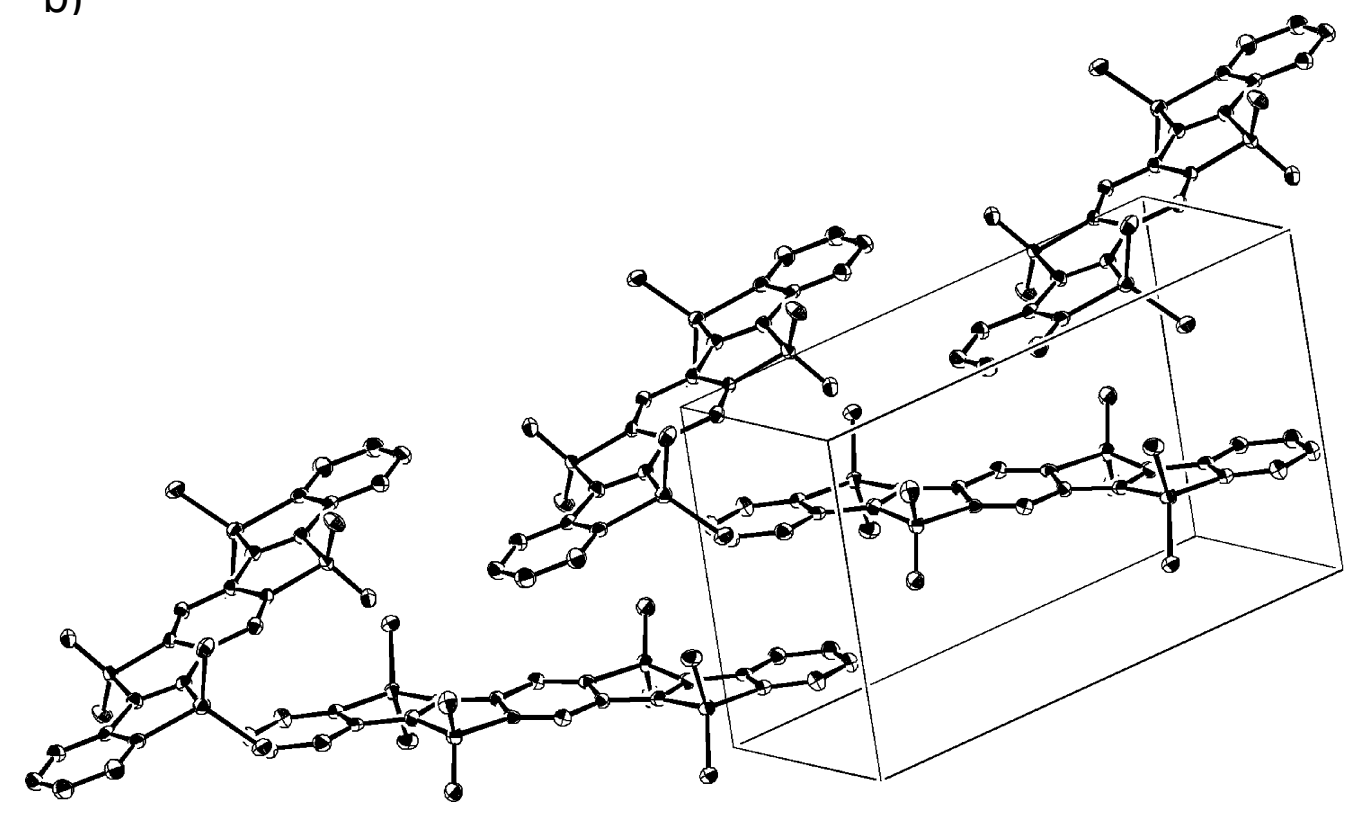

Figure S5. ORTEP drawing of $\mathbf{6 b}$ (50\% probability for thermal ellipsoids): a) a perspective view and b) a packing structure. Hydrogen atoms are omitted for clarity. 
NMR Spectra

${ }^{1} \mathrm{H}$ NMR of $8\left(400 \mathrm{MHz}, \mathrm{CDCl}_{3}\right)$

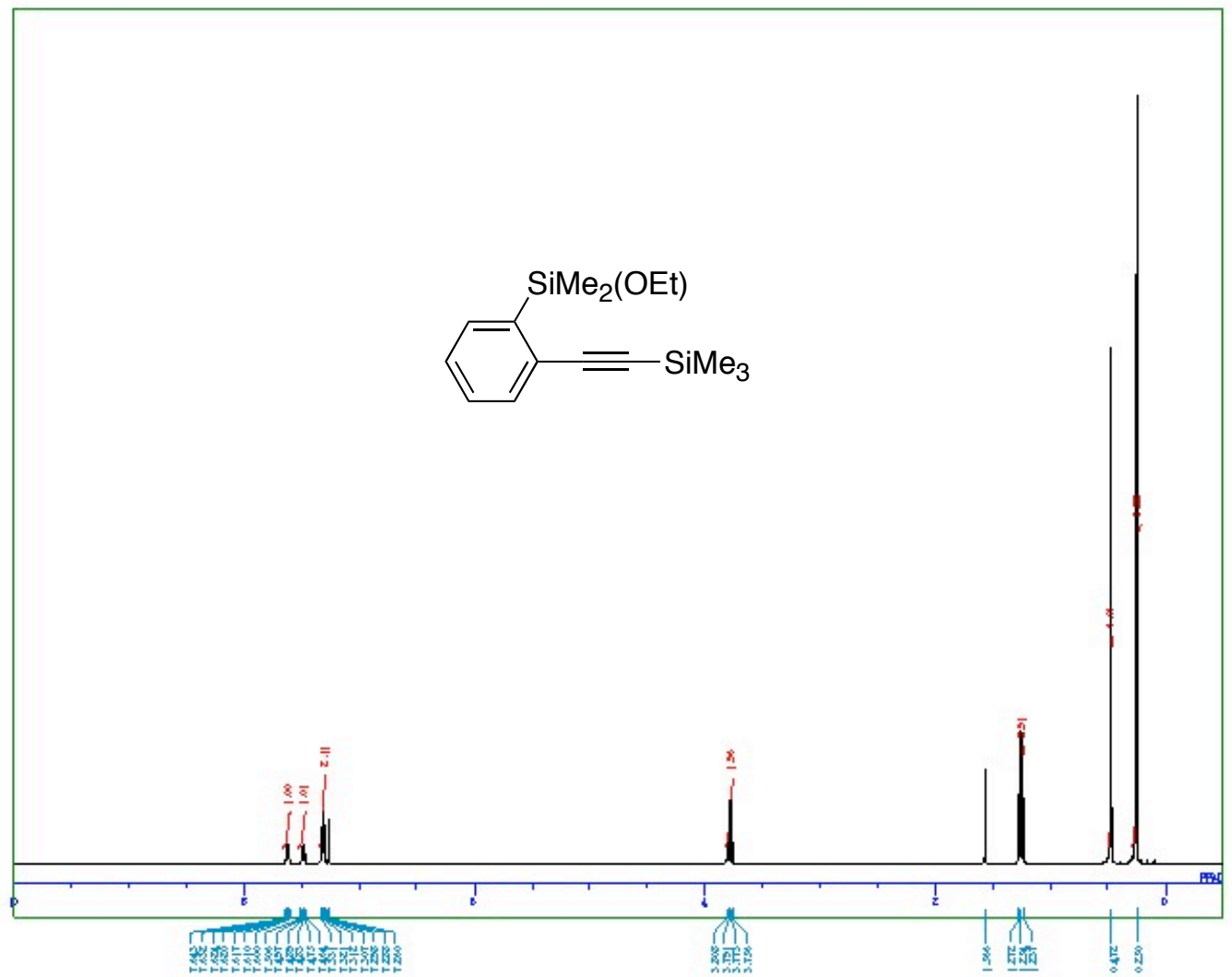

${ }^{13} \mathrm{C}$ NMR of $8\left(100 \mathrm{MHz}, \mathrm{CDCl}_{3}\right)$

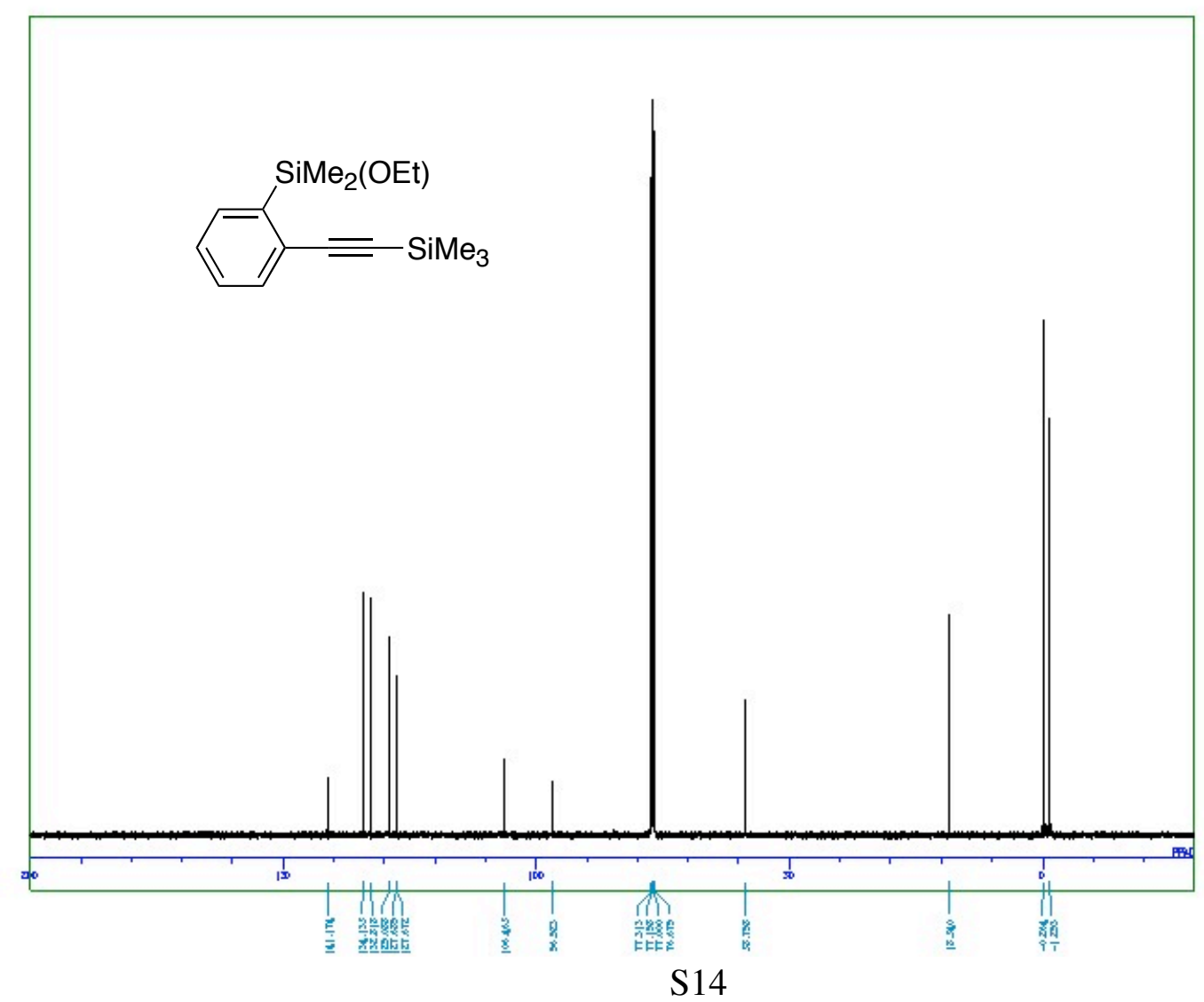


${ }^{1} \mathrm{H}$ NMR of $9\left(400 \mathrm{MHz}, \mathrm{CDCl}_{3}\right)$

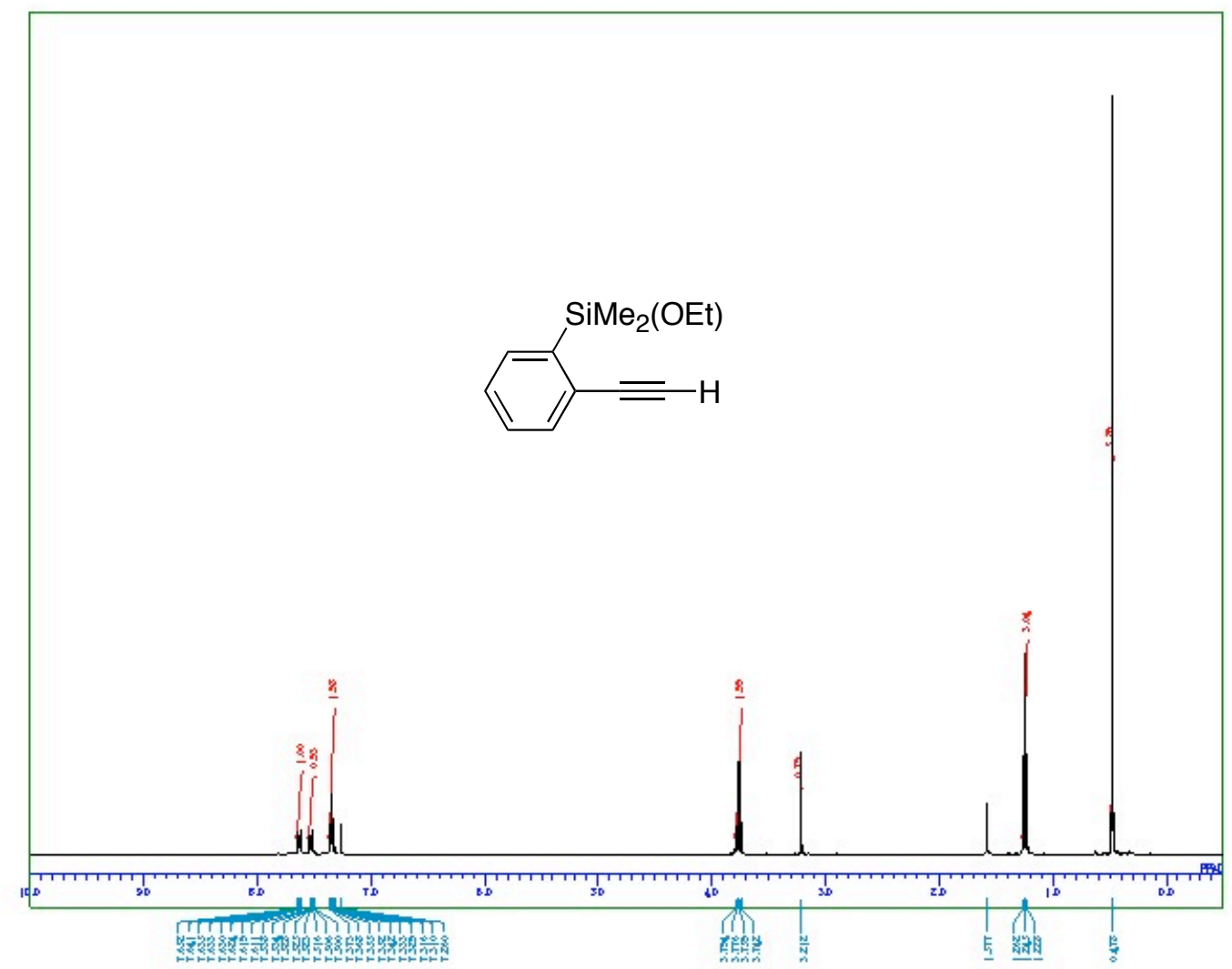

${ }^{13} \mathrm{C}$ NMR of $9\left(100 \mathrm{MHz}, \mathrm{CDCl}_{3}\right)$

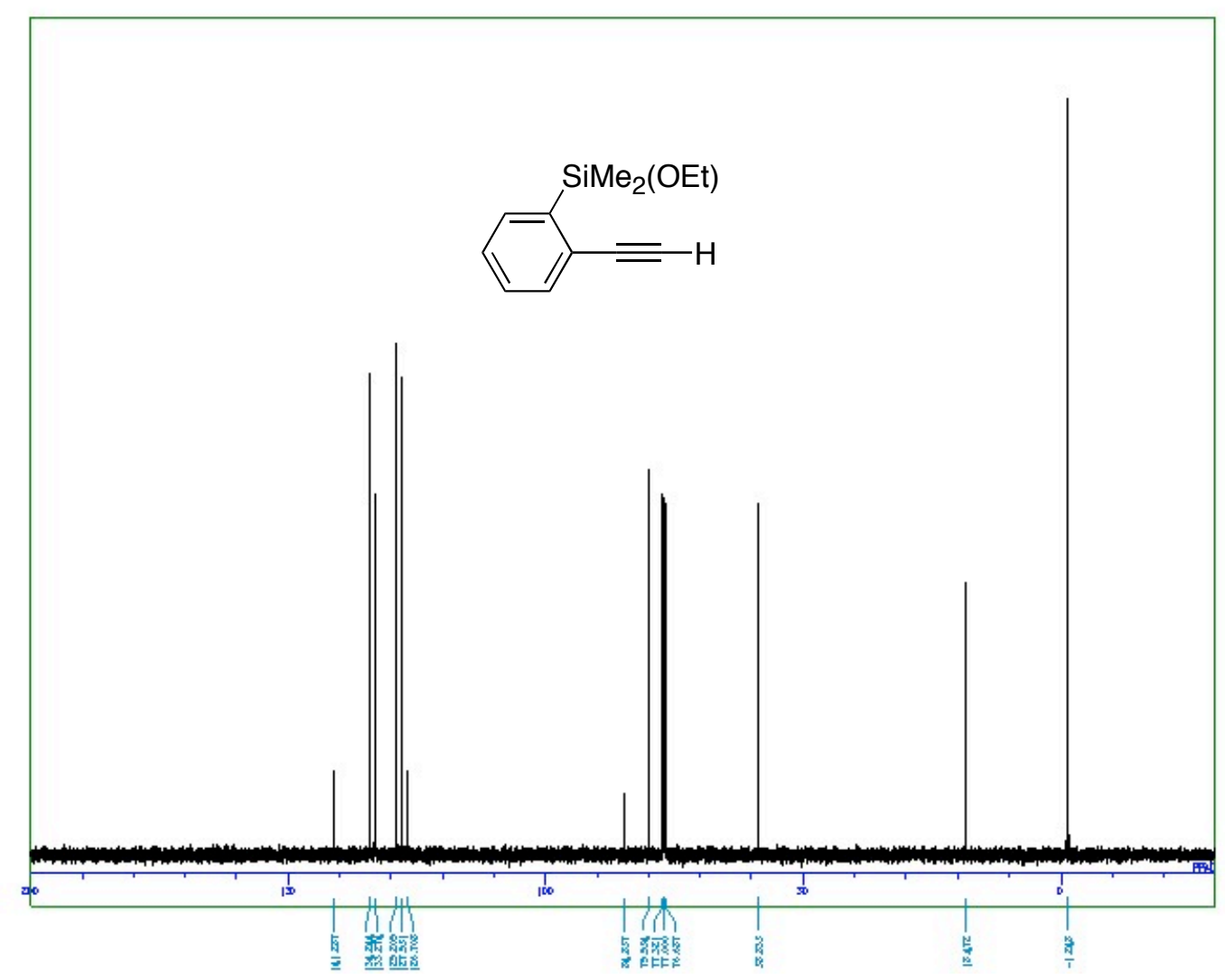


${ }^{1} \mathrm{H}$ NMR of $1\left(400 \mathrm{MHz}, \mathrm{CDCl}_{3}\right)$

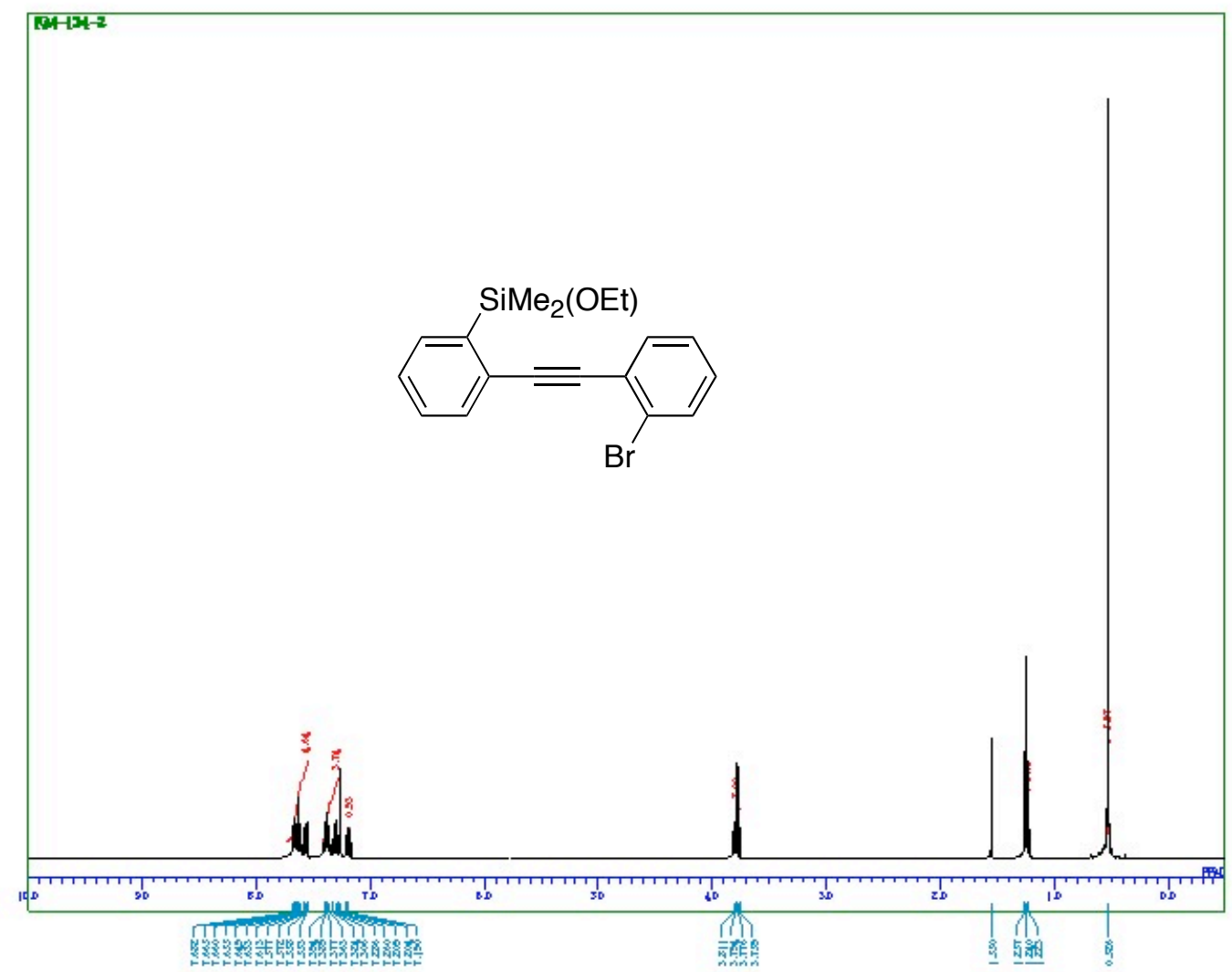

${ }^{13} \mathrm{C}$ NMR of $1\left(100 \mathrm{MHz}, \mathrm{CDCl}_{3}\right)$

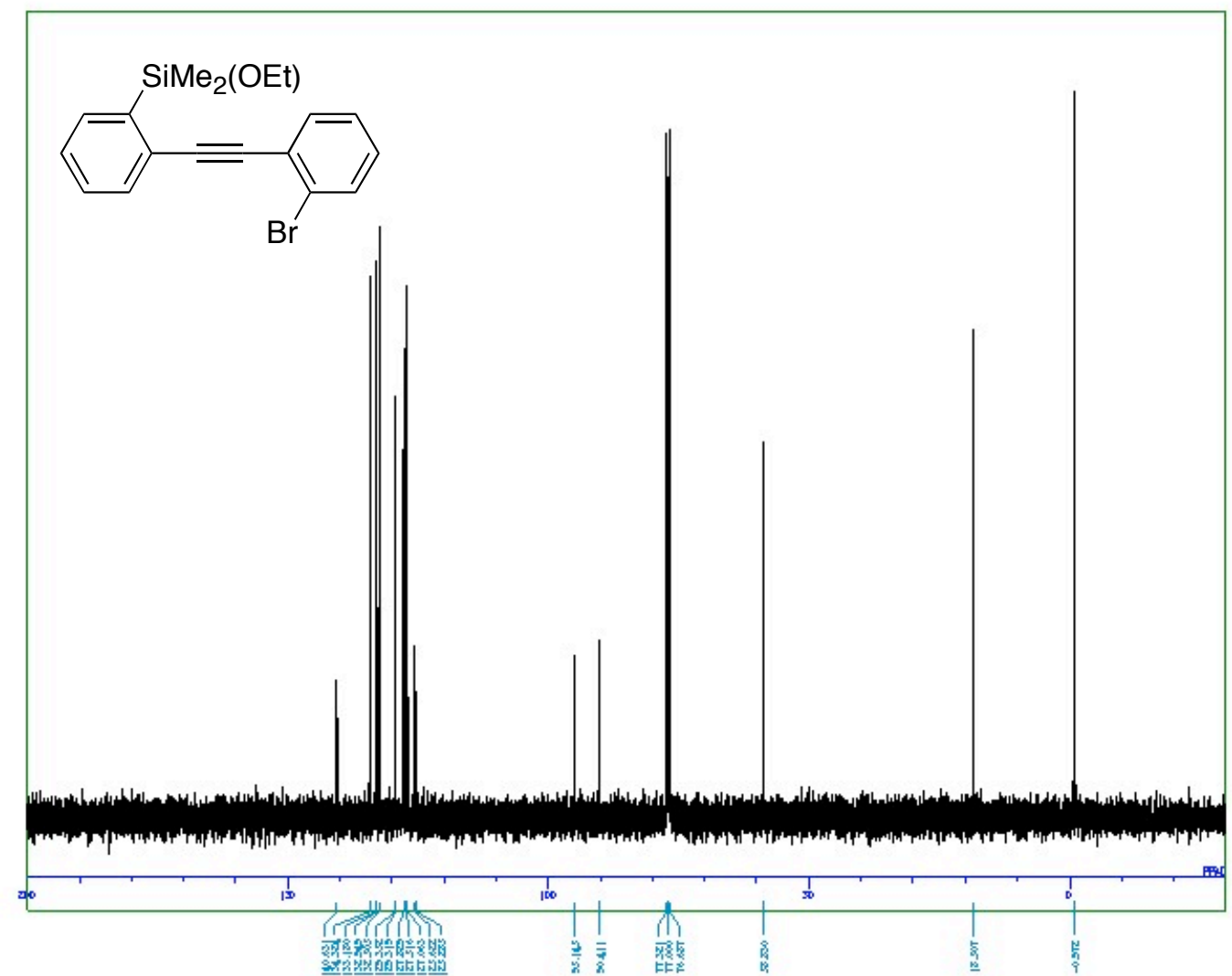


${ }^{1} \mathrm{H}$ NMR of $\mathbf{4 b}\left(400 \mathrm{MHz}, \mathrm{CDCl}_{3}\right)$

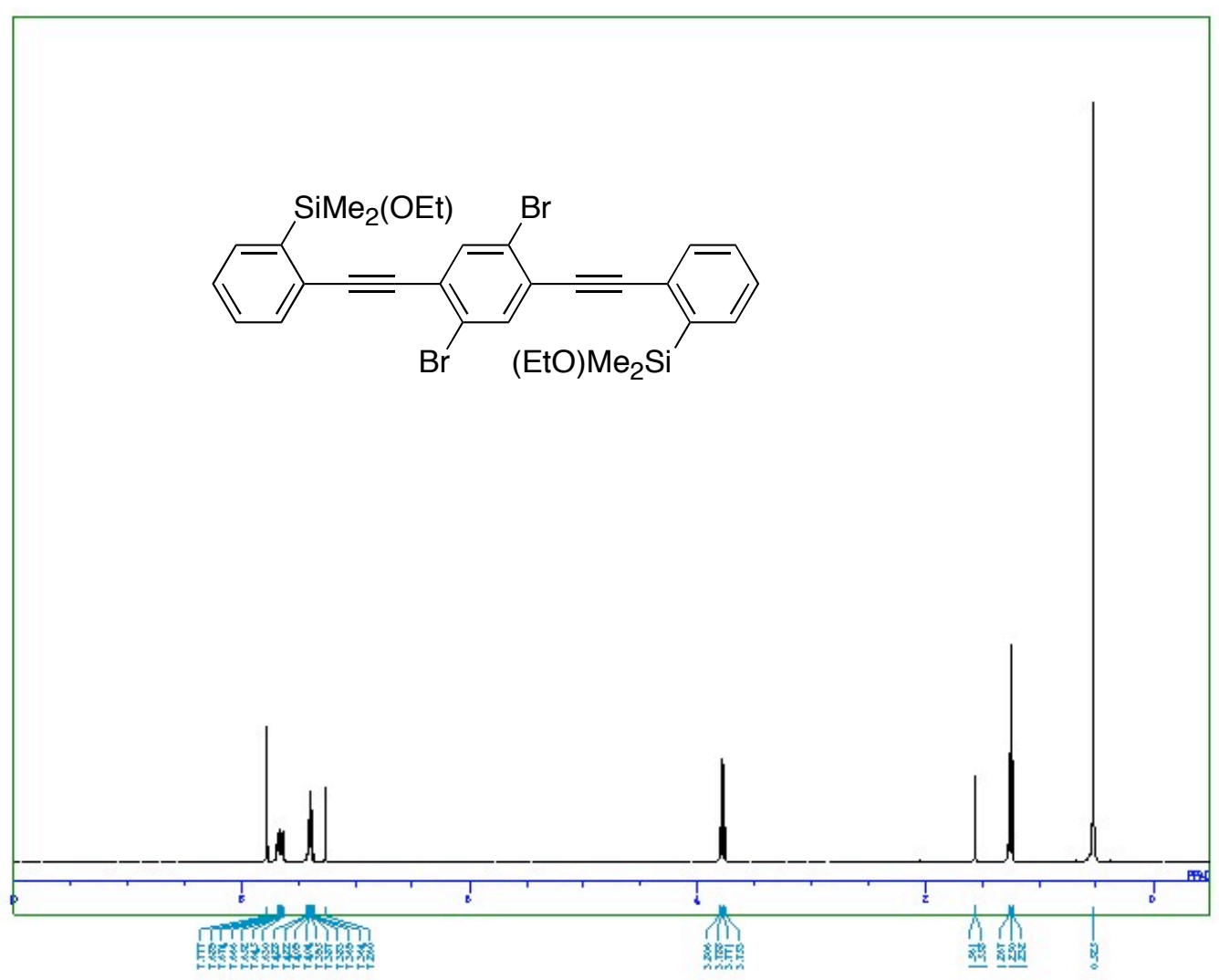

${ }^{13} \mathrm{C}$ NMR of $\mathbf{4 b}\left(100 \mathrm{MHz}, \mathrm{CDCl}_{3}\right)$

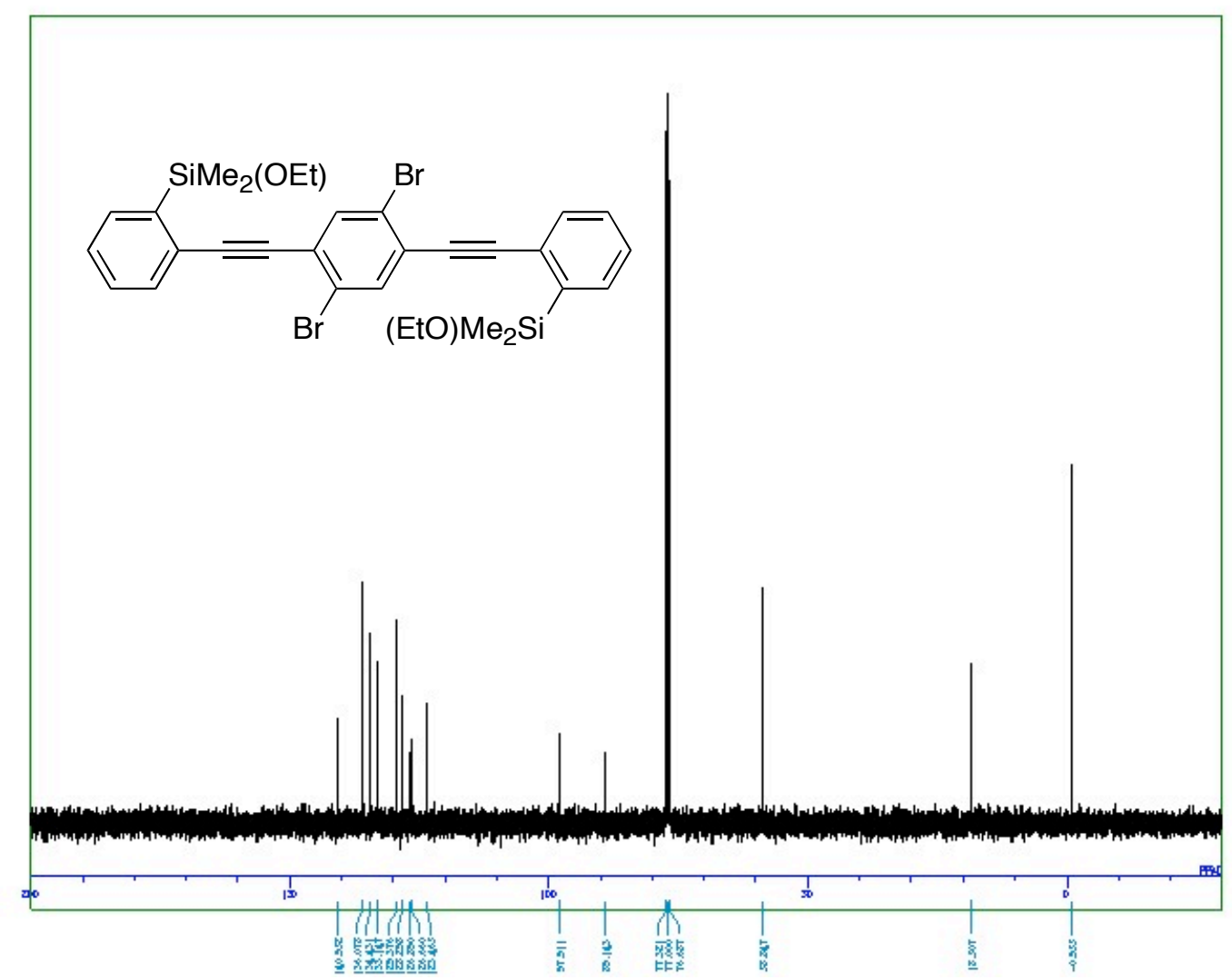


${ }^{1} \mathrm{H}$ NMR of $\mathbf{1 0}\left(400 \mathrm{MHz}, \mathrm{CDCl}_{3}\right)$

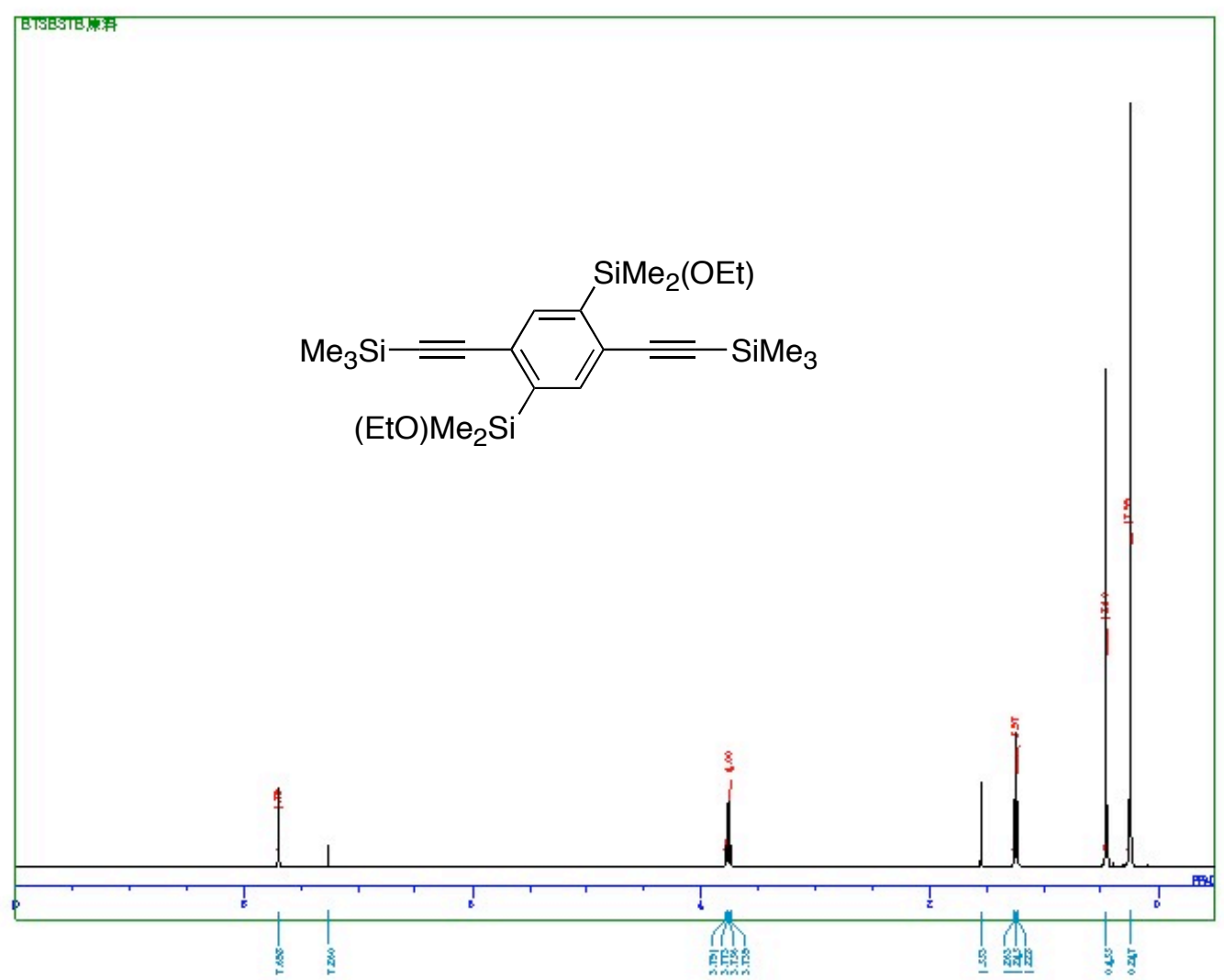

${ }^{13} \mathrm{C}$ NMR of $\mathbf{1 0}\left(100 \mathrm{MHz}, \mathrm{CDCl}_{3}\right)$

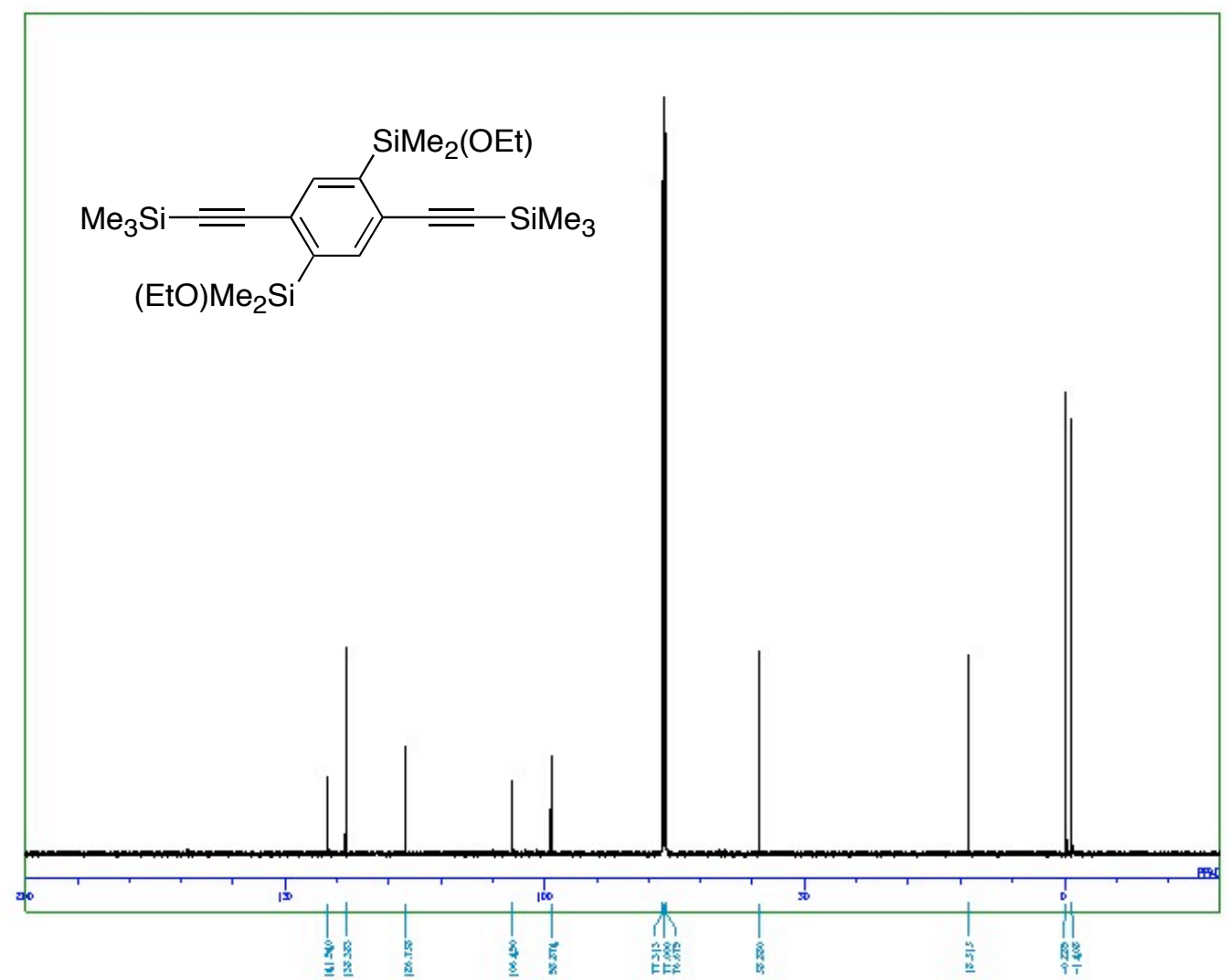


${ }^{1} \mathrm{H}$ NMR of $11\left(400 \mathrm{MHz}, \mathrm{CDCl}_{3}\right)$

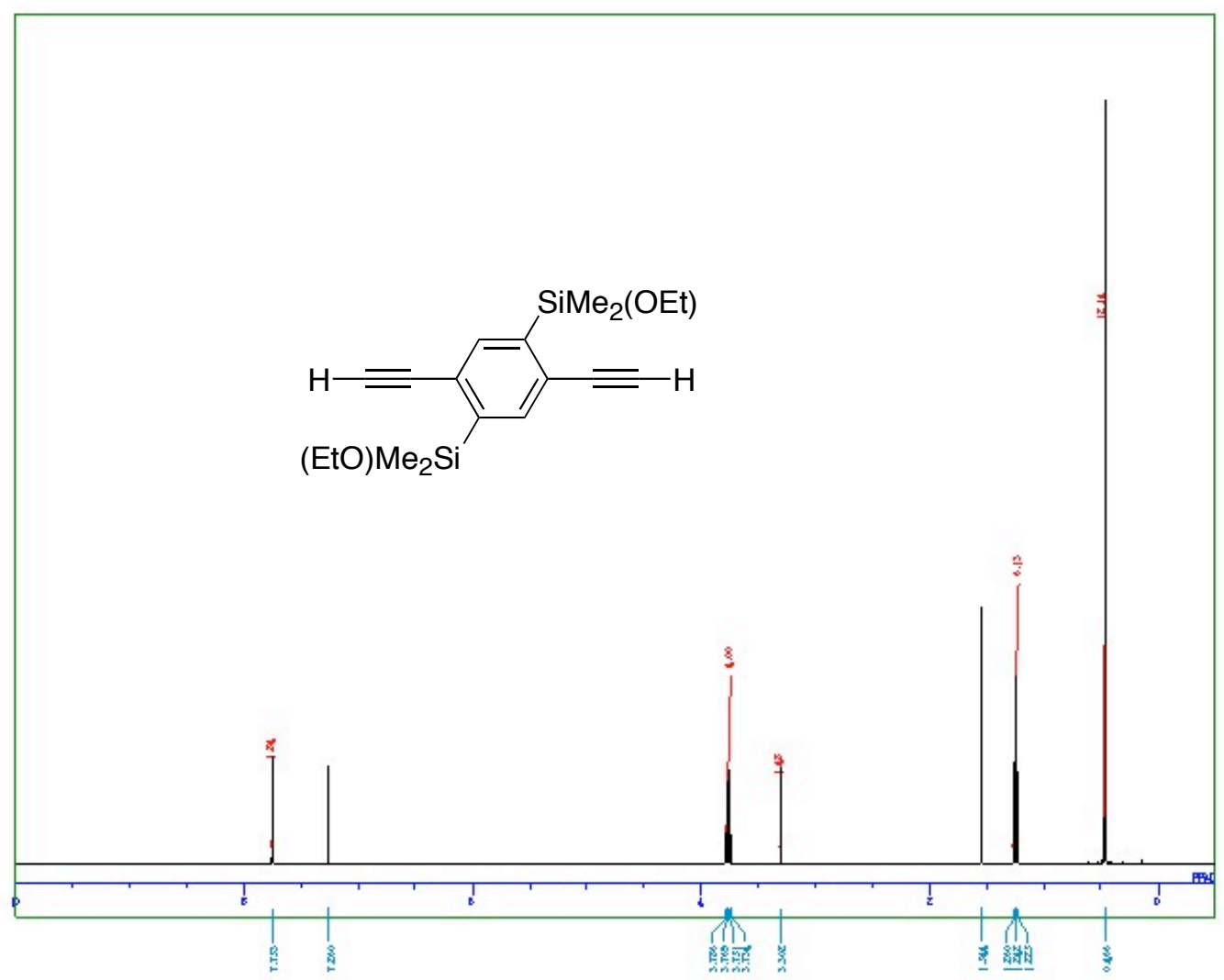

${ }^{13} \mathrm{C}$ NMR of $11\left(100 \mathrm{MHz}, \mathrm{CDCl}_{3}\right)$

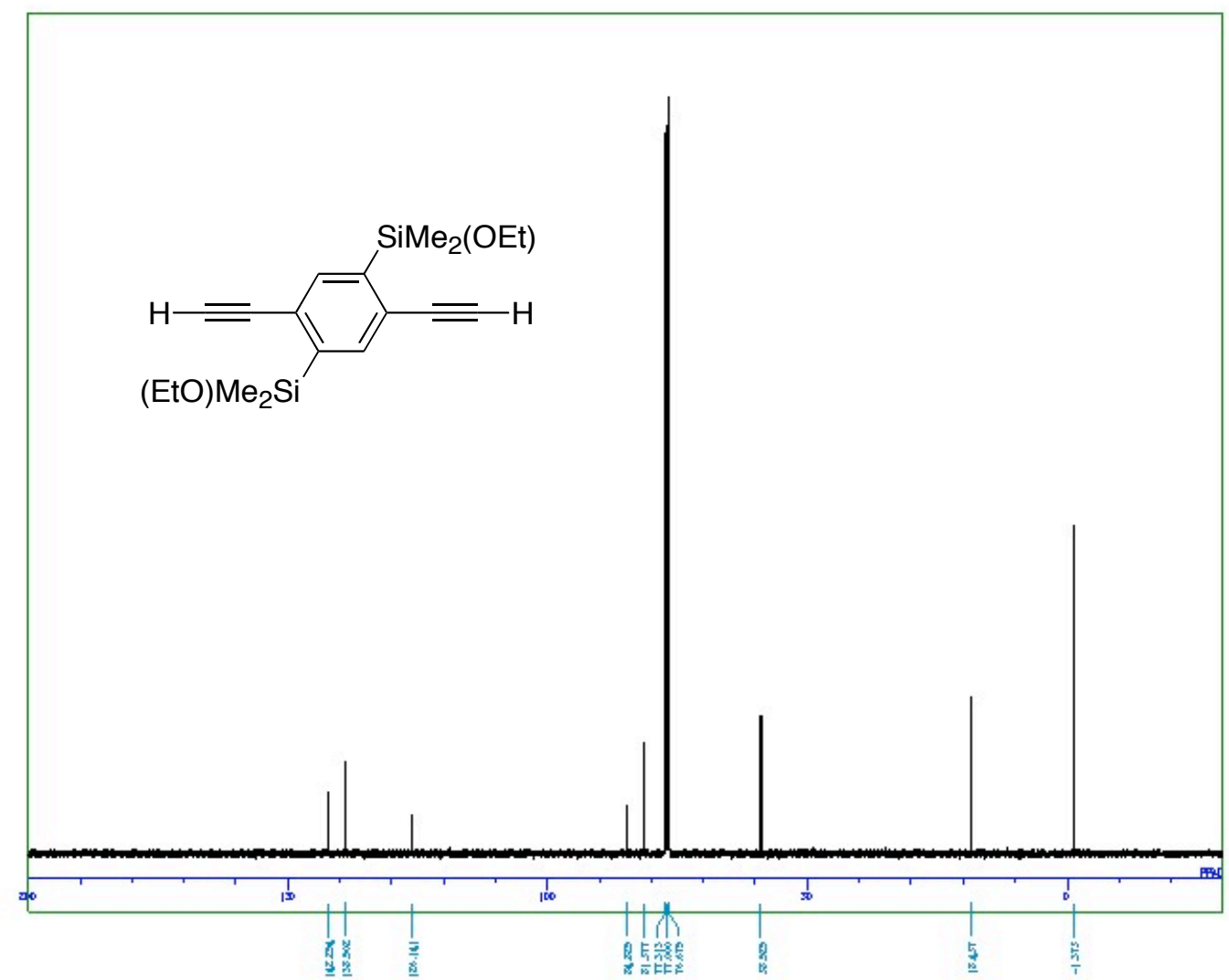


${ }^{1} \mathrm{H}$ NMR of $\mathbf{4 a}\left(400 \mathrm{MHz}, \mathrm{CDCl}_{3}\right)$

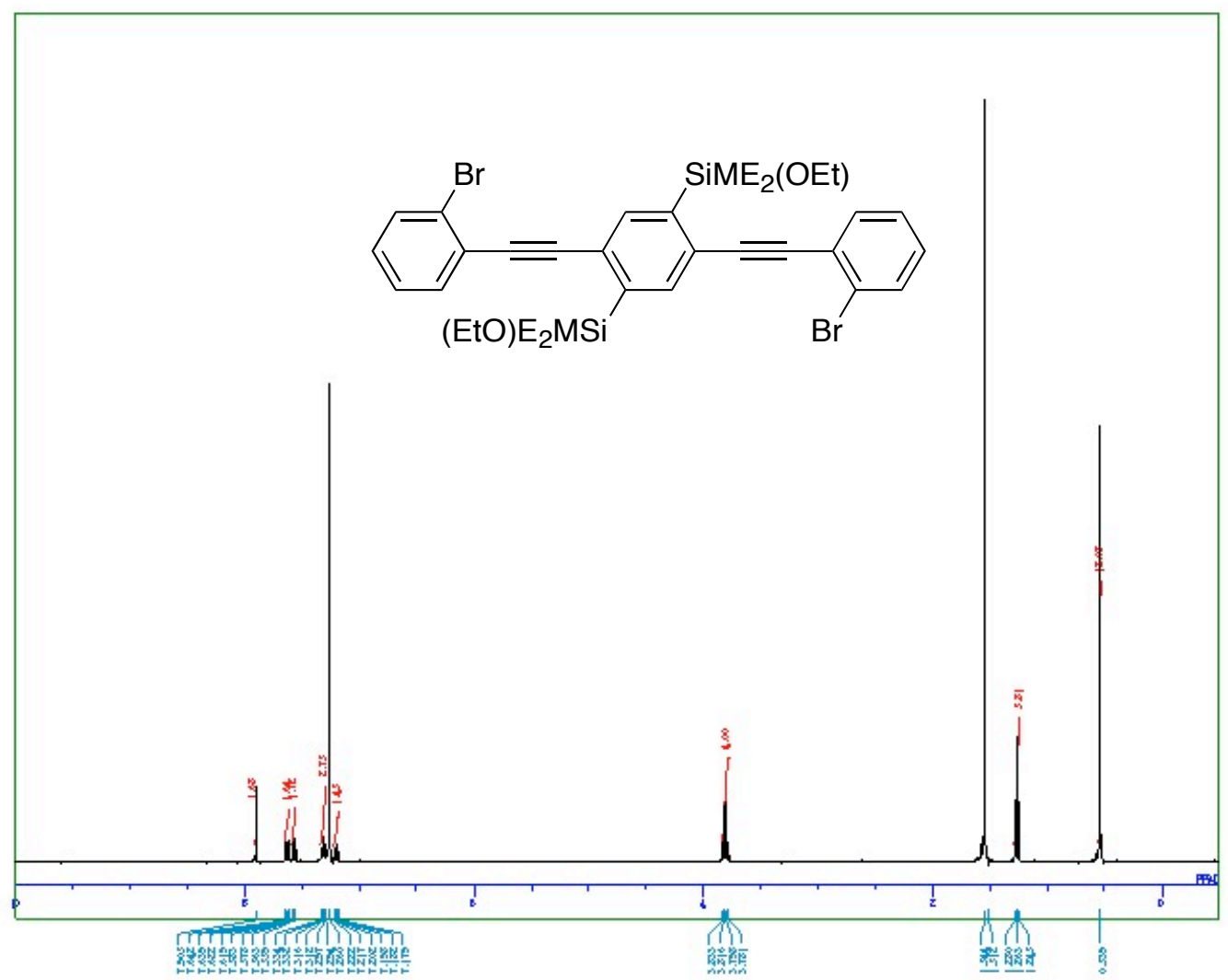

${ }^{13} \mathrm{C} \mathrm{NMR}$ of $\mathbf{4 a}\left(100 \mathrm{MHz}, \mathrm{CDCl}_{3}\right)$

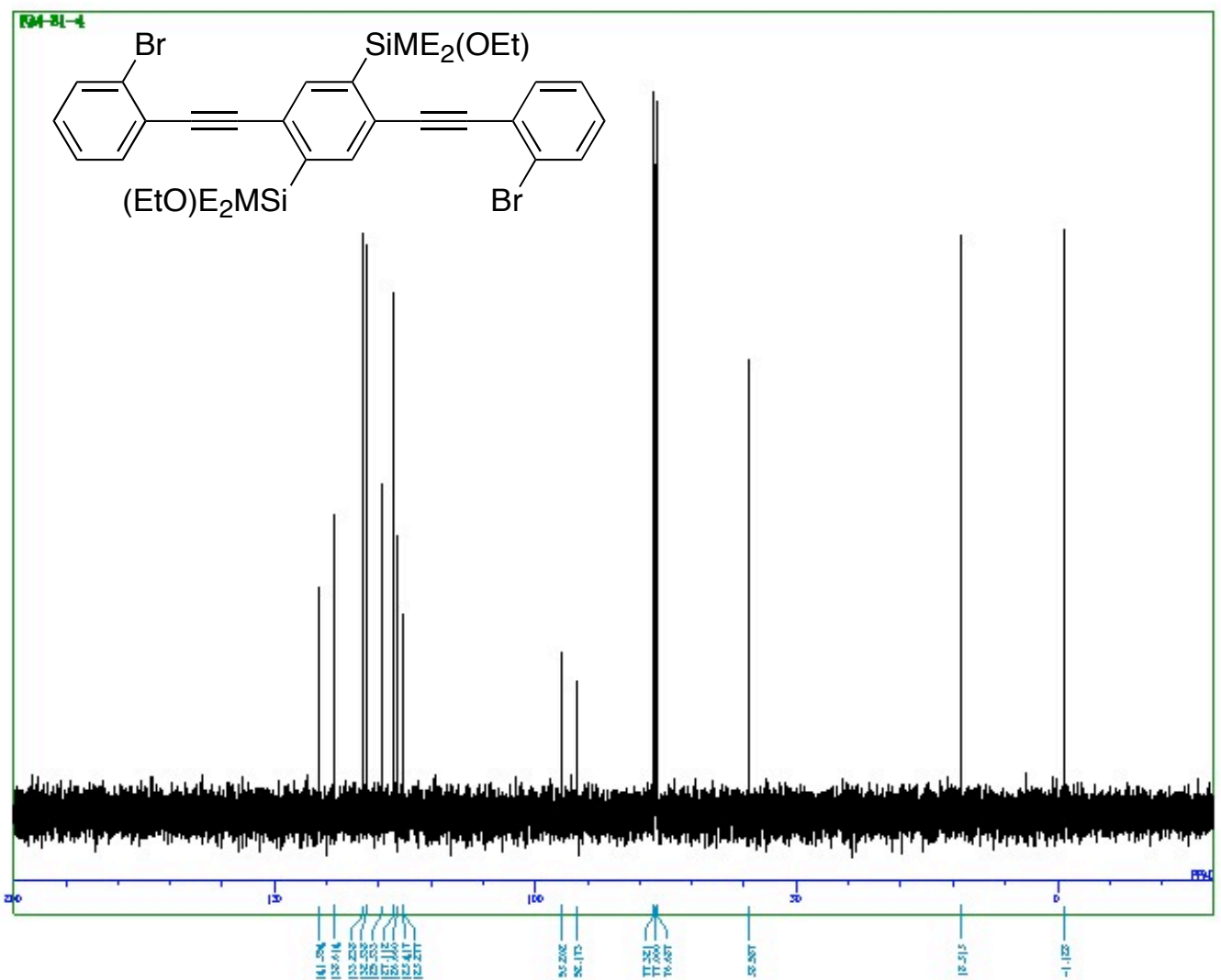


${ }^{1} \mathrm{H}$ NMR of $\mathbf{5 a}\left(400 \mathrm{MHz}, \mathrm{CDCl}_{3}\right)$

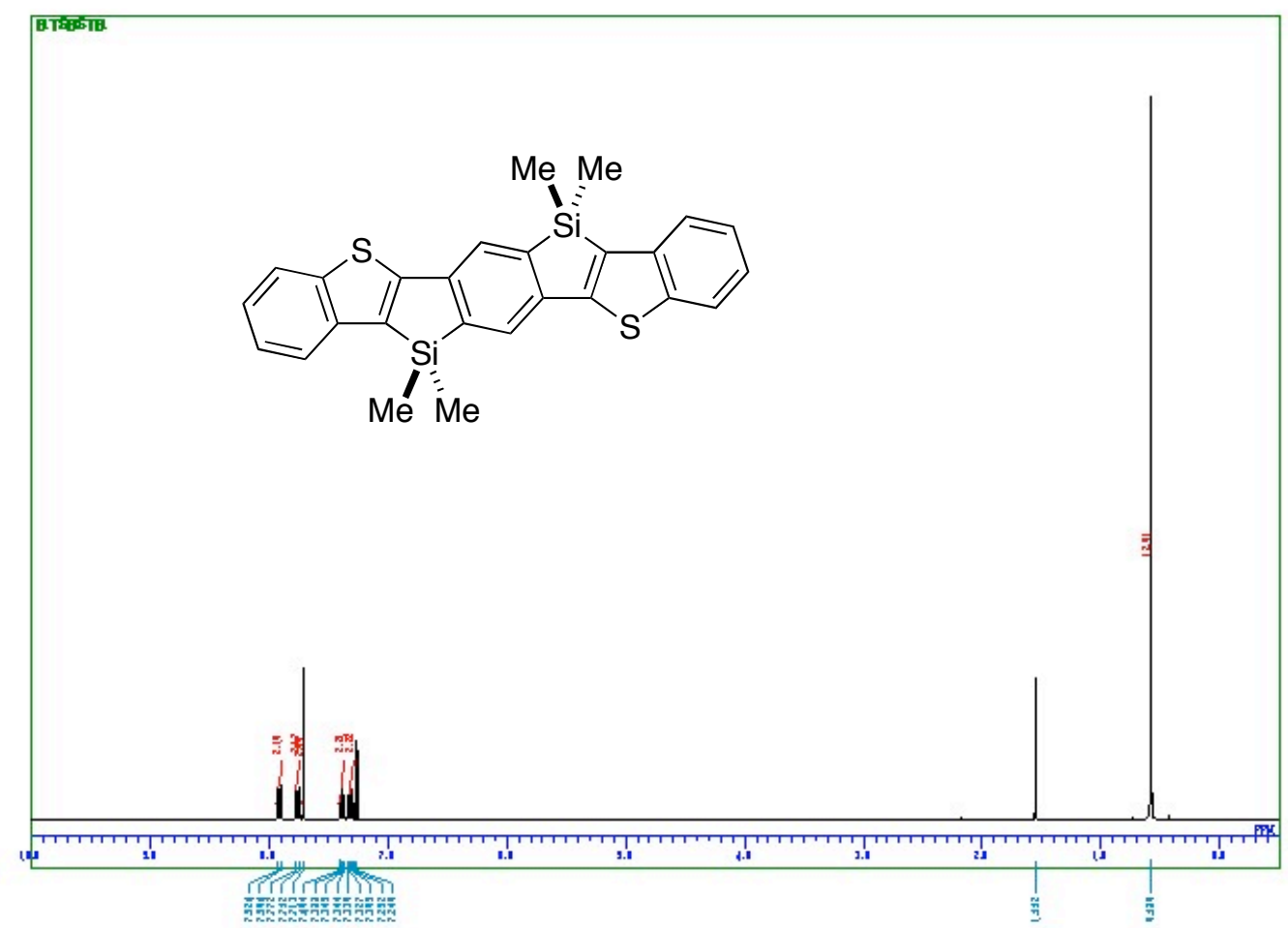

${ }^{13} \mathrm{C}$ NMR of $5 \mathbf{a}\left(100 \mathrm{MHz}, \mathrm{CDCl}_{3}\right)$

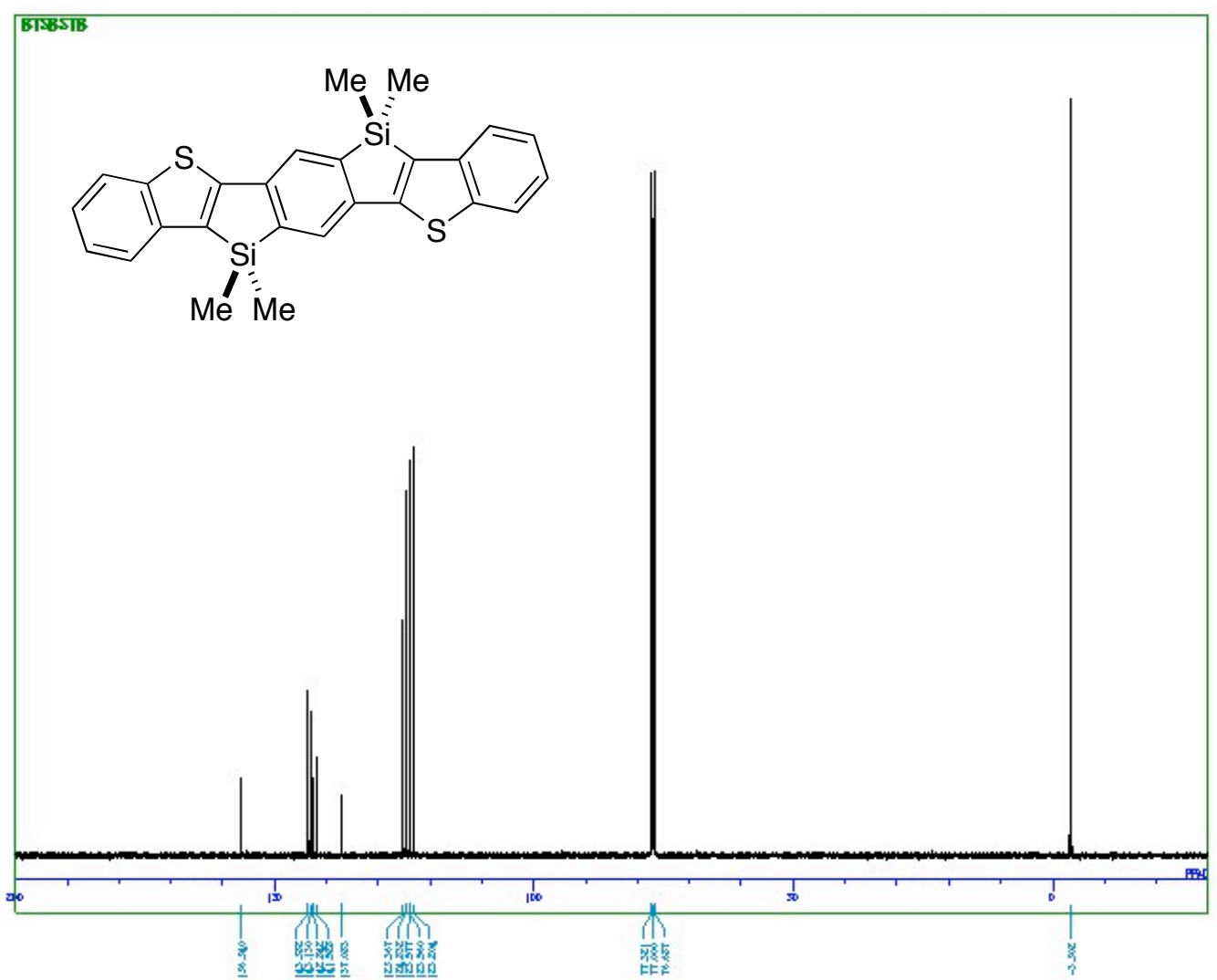


${ }^{1} \mathrm{H}$ NMR of $\mathbf{5 b}\left(400 \mathrm{MHz}, \mathrm{CDCl}_{3}\right)$

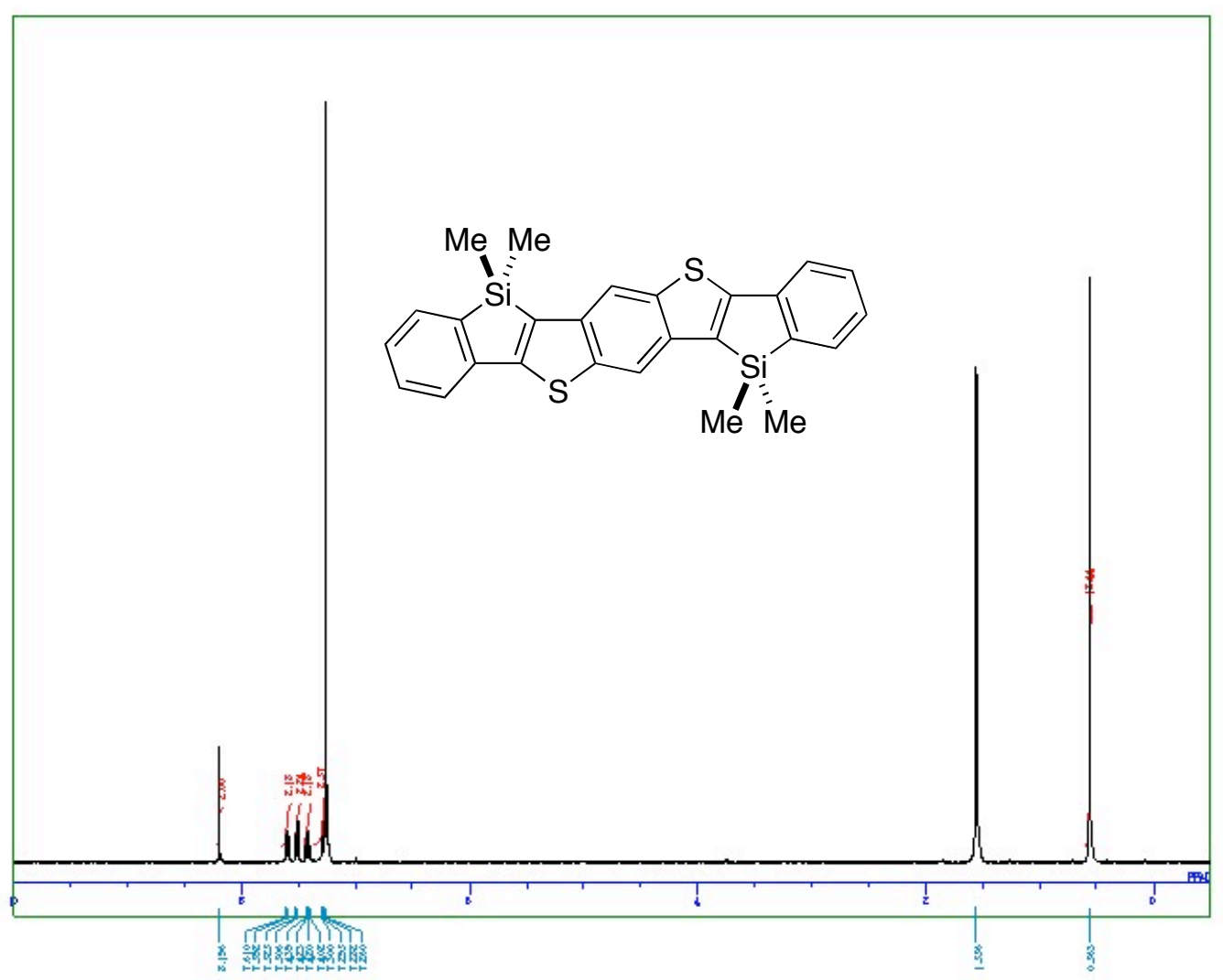

${ }^{13} \mathrm{C}$ NMR of $\mathbf{5 b}\left(100 \mathrm{MHz}, \mathrm{CDCl}_{3}\right)$

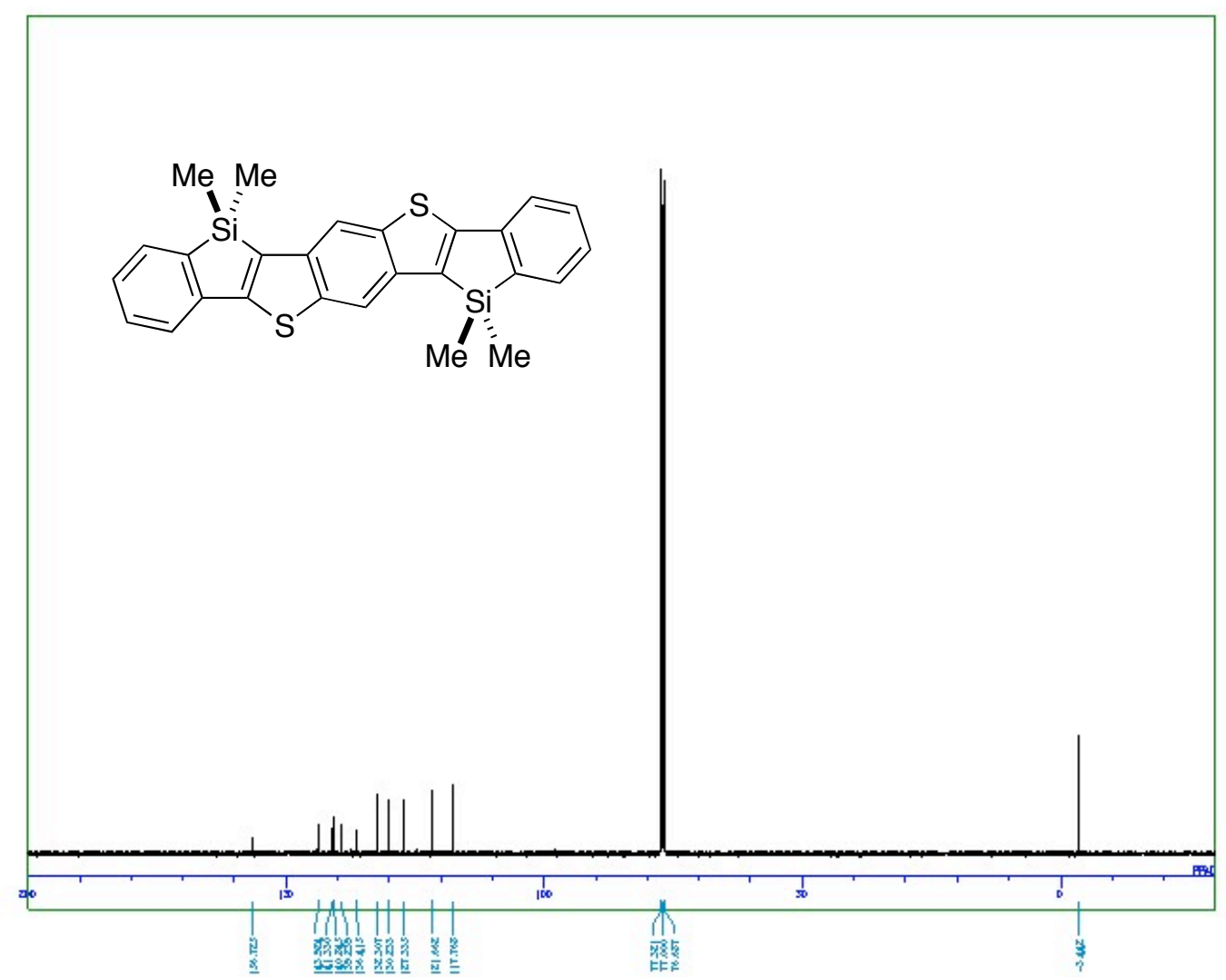


${ }^{1} \mathrm{H}$ NMR of $\mathbf{5 c}\left(400 \mathrm{MHz}, \mathrm{CDCl}_{3}\right)$

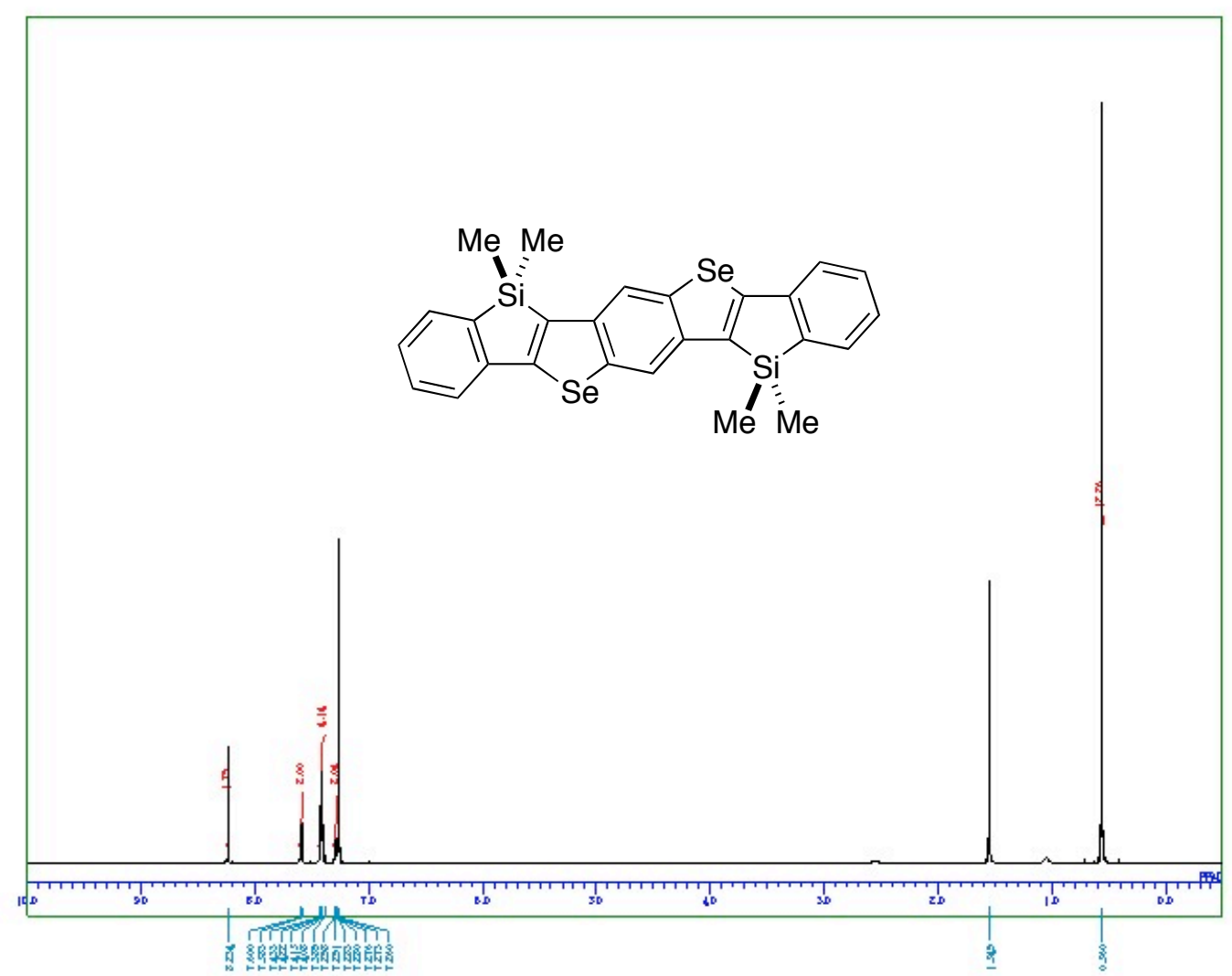

${ }^{13} \mathrm{C}$ NMR of $\mathbf{5 c}\left(100 \mathrm{MHz}, \mathrm{CDCl}_{3}\right)$

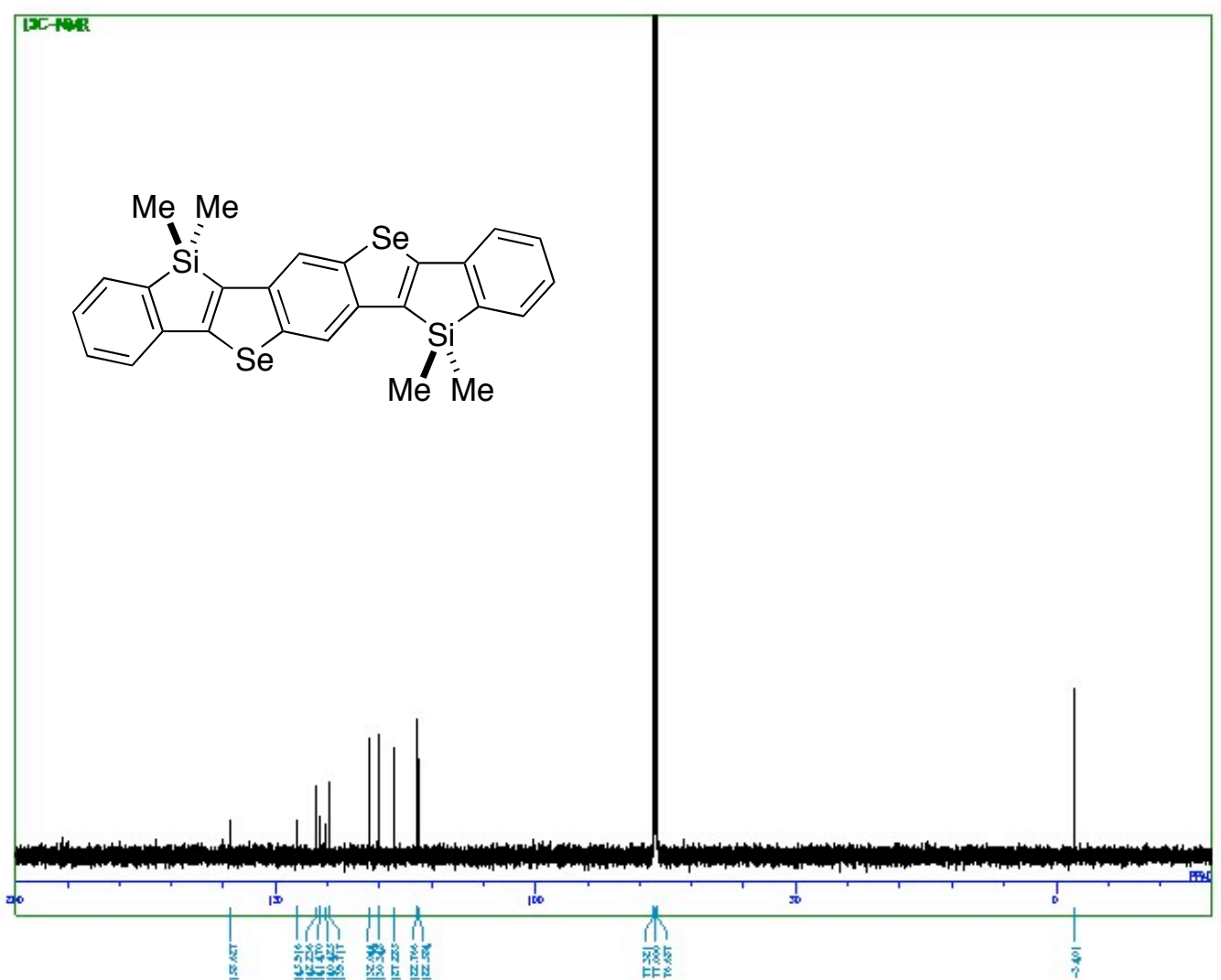


${ }^{1} \mathrm{H}$ NMR of $\mathbf{6 a}\left(400 \mathrm{MHz}, \mathrm{CDCl}_{3}\right)$

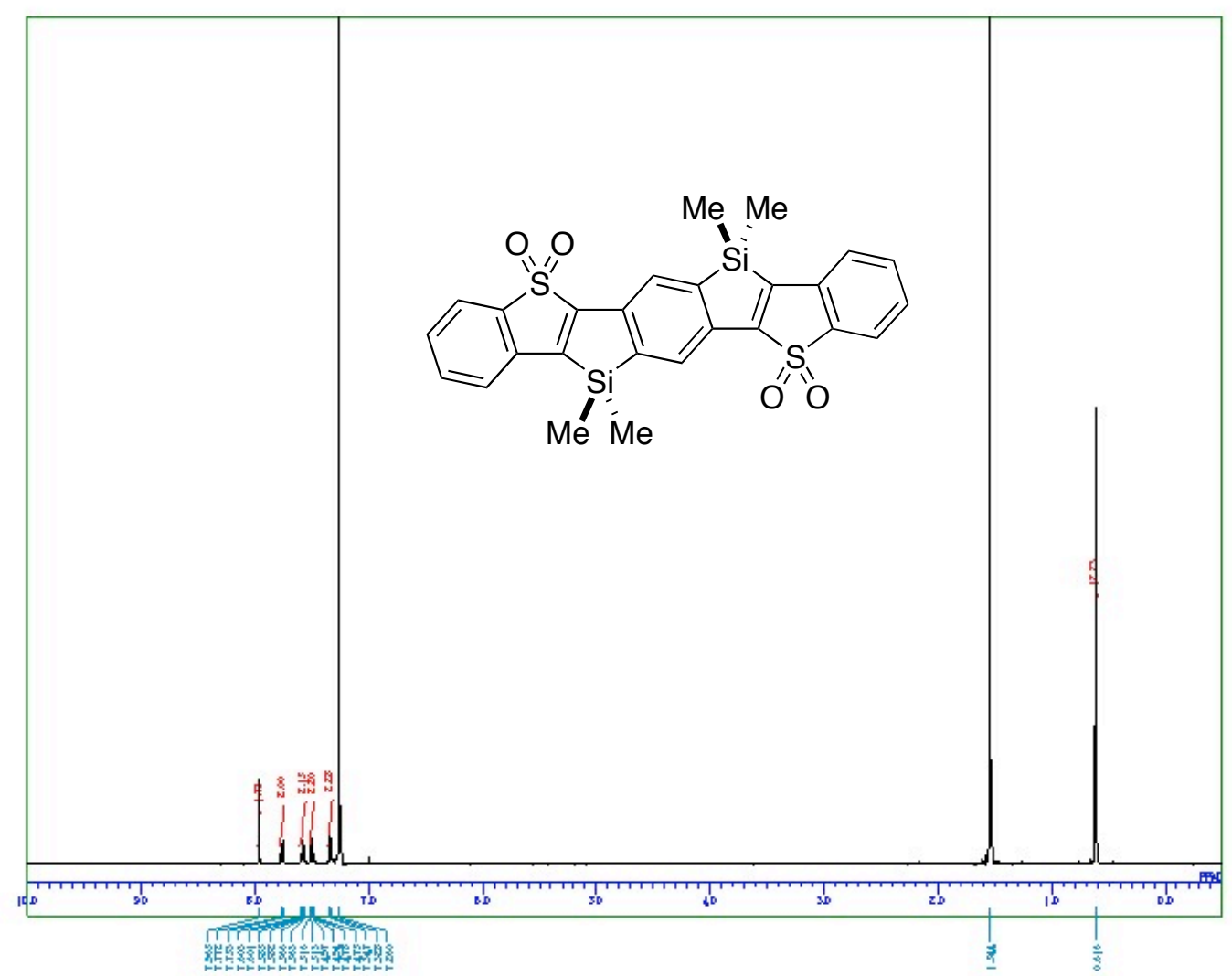

${ }^{13} \mathrm{C}$ NMR of 6a (100 MHz, $\left.\mathrm{CDCl}_{3}\right)$

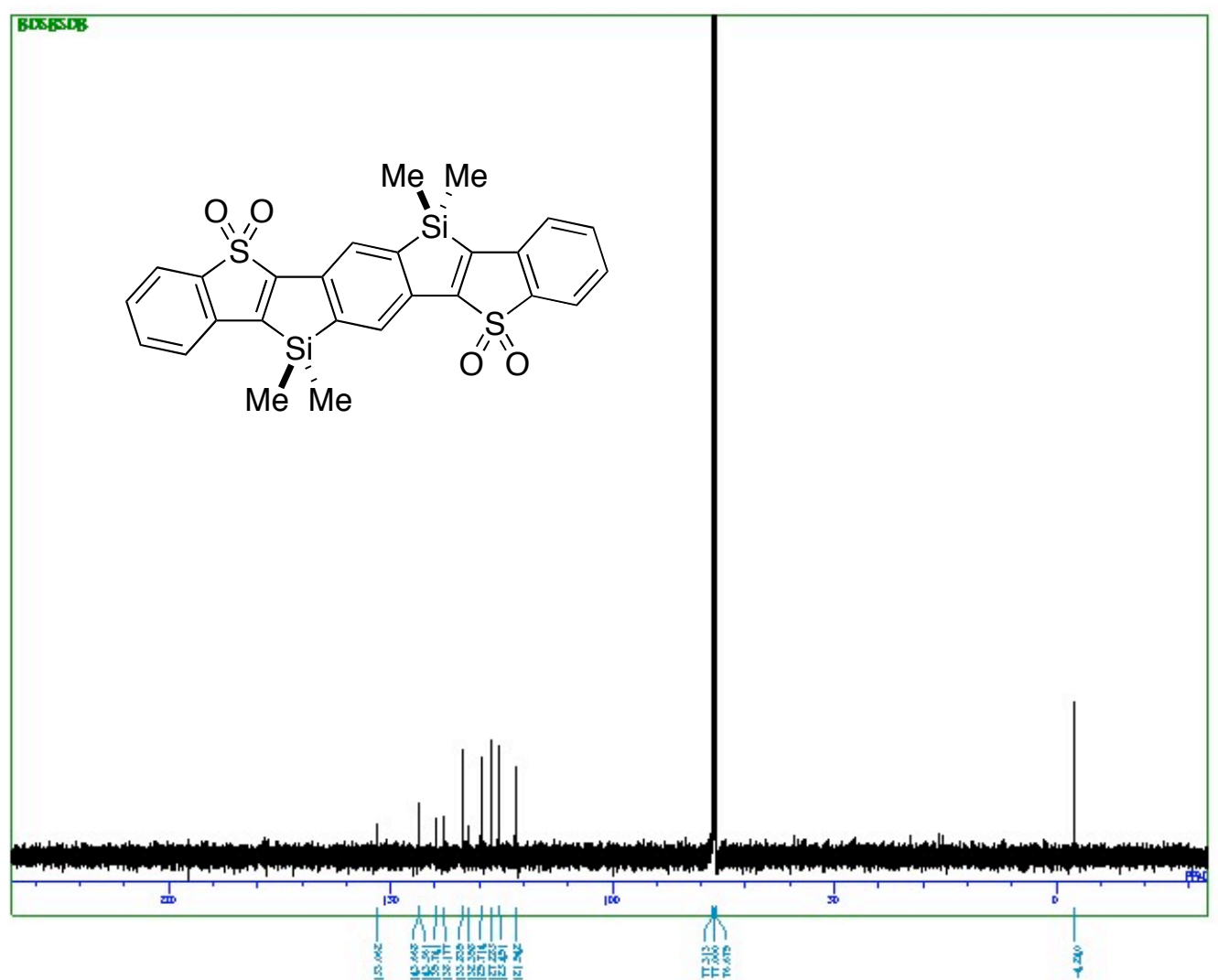


${ }^{1} \mathrm{H}$ NMR of $\mathbf{6 b}\left(400 \mathrm{MHz}, \mathrm{CDCl}_{3}\right)$

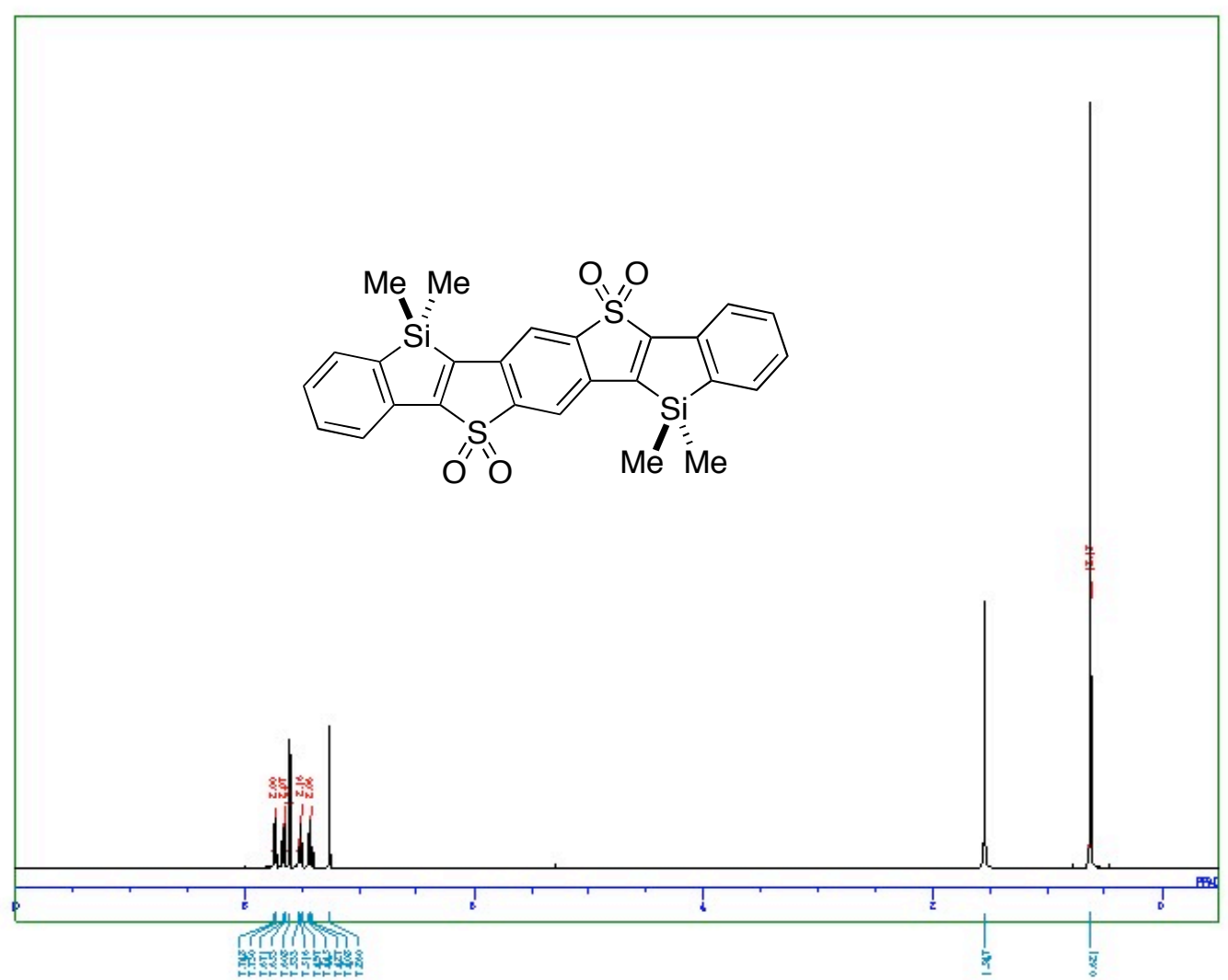

${ }^{13} \mathrm{C}$ NMR of $\mathbf{6 b}\left(100 \mathrm{MHz}, \mathrm{CDCl}_{3}\right)$

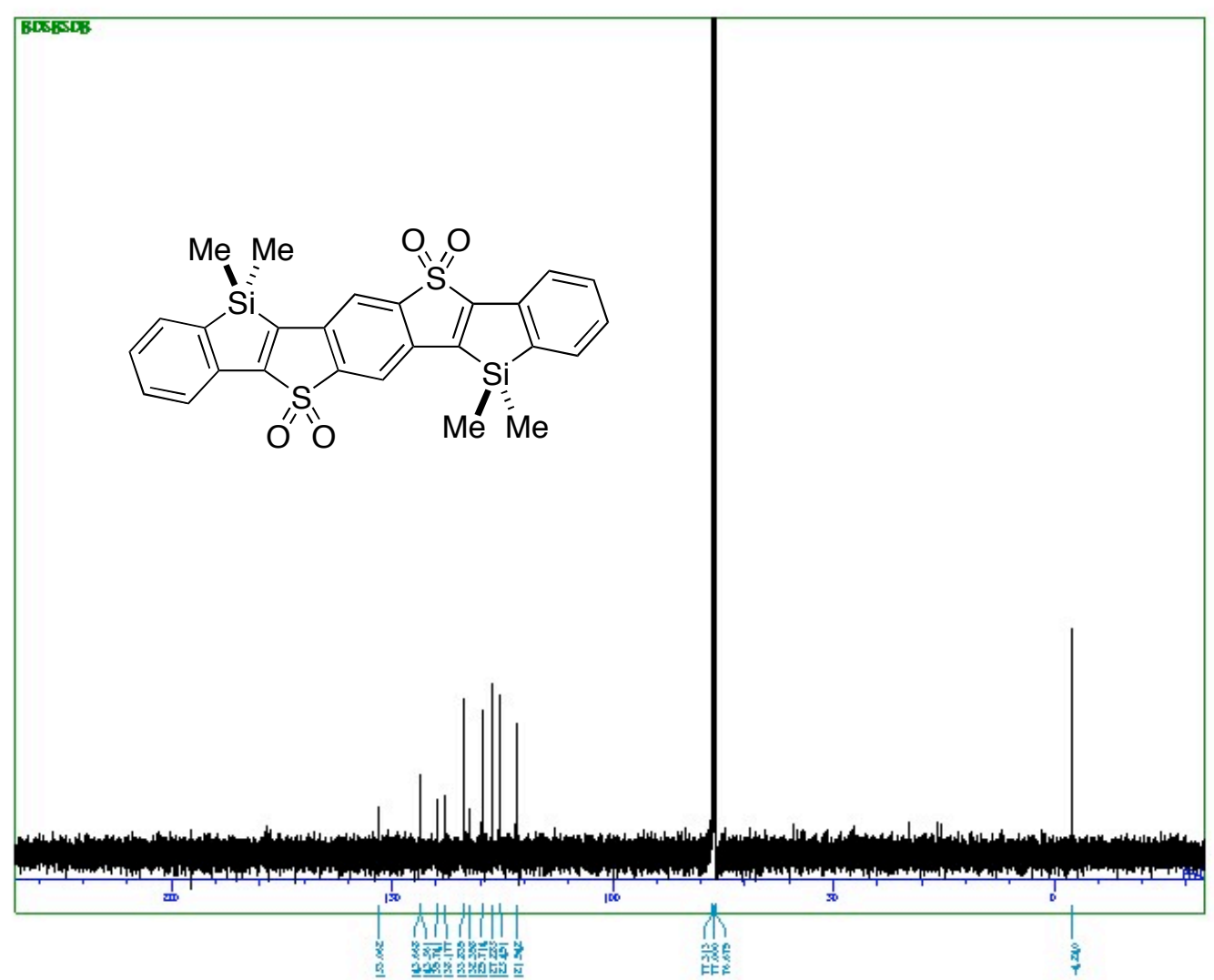

